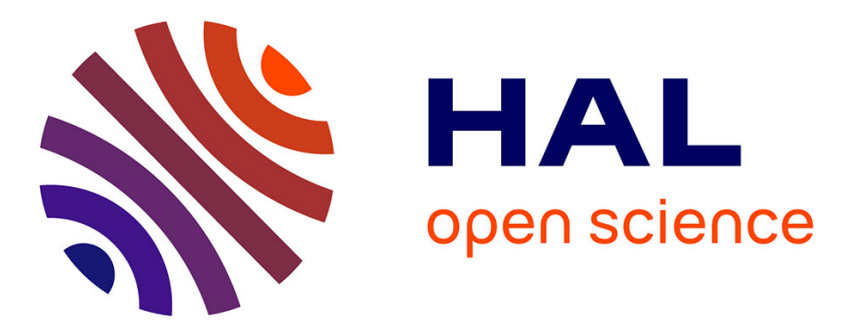

\title{
Better residential than ethnic discrimination!: Reconciling audit's and interview findings in the Parisian housing market
}

François Bonnet, Etienne Lalé, Mirna Safi, Etienne Wasmer

\section{- To cite this version:}

François Bonnet, Etienne Lalé, Mirna Safi, Etienne Wasmer. Better residential than ethnic discrimination!: Reconciling audit's and interview findings in the Parisian housing market. Urban Studies, 2016, 53 (13), pp.2815-2833. 10.1177/0042098015596107 . hal-01112450

HAL Id: hal-01112450

https://hal-sciencespo.archives-ouvertes.fr/hal-01112450

Submitted on 2 Feb 2015

HAL is a multi-disciplinary open access archive for the deposit and dissemination of scientific research documents, whether they are published or not. The documents may come from teaching and research institutions in France or abroad, or from public or private research centers.
L'archive ouverte pluridisciplinaire HAL, est destinée au dépôt et à la diffusion de documents scientifiques de niveau recherche, publiés ou non, émanant des établissements d'enseignement et de recherche français ou étrangers, des laboratoires publics ou privés. 


\section{SciencesPo.}

Laboratoire interdisciplinaire d'évaluation des politiques publiques

LIEPP Working Paper

February 2015, n³6

Better residential than ethnic discrimination!

Reconciling audit's findings and interviews' findings in the Parisian housing market

\section{François Bonnet}

CNRS Pacte - Université de Grenoble Alpes

françois.bonnet@iepg.fr

Etienne Lalé

Department of Economics, University of Bristol

etienne.lale@bristol.ac.uk

\section{Mirna Safi}

Department of sociology, Sciences Po OSC, CNRS, LIEPP

mirna.safi@sciencespo.fr

Etienne Wasmer

Sciences Po, Department of Economics and LIEPP

etienne.wasmer@sciencespo.fr

(c) 2015 by the authors. All rights reserved. 


\title{
Better residential than ethnic discrimination! Reconciling audit's findings and interviews' findings in the Parisian housing market*
}

François Bonnet ${ }^{\dagger}$ Etienne Lalé $\$$ Mirna Safi§, Etienne Wasmer ${ }^{\mathbb{I}}$

January 2015

\begin{abstract}
This article investigates discrimination and the interplay of residential and ethnic stigma on the French housing market using two different methods, paired-testing audit study of real estate agencies and face-to-face interviews with real estate agents. The juxtaposition of their findings leads to a paradox: interviews reveal high levels of ethnic discrimination but little to none residential discrimination, while the audit study shows that living in deprived suburbs is associated with a lower probability of obtaining an appointment for a housing vacancy but ethnic origin (signaled by the candidate's name) has no significant discriminatory effect. We have three priors potentially consistent with this apparent paradox and re-evaluate their likelihood in light of these findings: (i) agents make use of any statistical information about insolvency, including residency; (ii) there are two distinct and independent taste discriminations, one about space and one about ethnicity; (iii) these two dimensions exist and complement each other.
\end{abstract}

Keywords: Discrimination, Neighborhood Effects, Housing Market

JEL codes: J71, R23

*This research was financed under the grants 2007 ANR-07-1210254 (DISCRI-SEGRE), ANR-10BLANC-1819-01(EVALPOLPUB), ANR-11-LABX-0091, ANR-11-IDEX-0005-02. We are grateful to Lorraine Pinto and Lucile Romanello for their contribution early on in this project. We also thank Aurélien Chauvier, Augustin Célier, Fatima Hocini, Mohamed El Dahshan, Alberic de Gayardon and Jean de SaintChéron for research assistance. Comments by participants at the Sciences Po workshop on discrimination and segregation, notably David Latin and Jeffrey Zax were most useful.

${ }^{\dagger}$ CNRS, Pacte - Université de Grenoble Alpes.

‡Corresponding author - Department of Economics, University of Bristol.

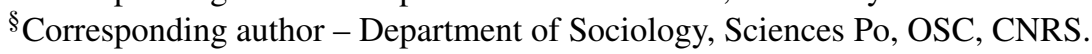

IISciences Po, Department of Economics and LIEPP. 


\section{Introduction}

The concentration of ethnic minorities in underprivileged neighborhoods is a stylized fact in Western societies (Johnston, Poulsen and Forrest, 2007; Musterd, 2005; Peach, Robinson and Smith, 1981). Emanating from discriminatory processes, ethnic segregation may also lead in turn to "residential traps" that affect minority populations' socioeconomic achievements, from access to education to economic success and the building of social networks (Crane, 1991; Sampson, Morenoff and Gannon-Rowley, 2002).

While there is a wide range of literature on the cumulative aspect of residential and ethnic/racial inequalities in the United States (Denton and Massey, 1993; Wilson, 1978, 1987), the interaction between ethnic and residential stigma has seldom been analyzed in audit studies on housing discrimination. The only exception we are aware of being a study of the credit market by Ross and Yinger (2002). ${ }^{1}$

In France, chronic urban riots in the banlieues over the last thirty years reinforce the idea of a French racial question (Waddington, Jobard and King, 2013). Still, urban studies in France rarely consider ethnicity in general and ethnic discrimination in the housing market in particular, despite some recent works providing evidence of a residential discrimination along with an ethnic one and reviewed in the next Section. By residential discrimination we refer to discriminatory decisions precisely oriented against the individual's residential area. Such practice has become explicitly illegal since Dec. 14, 2013 in France: "residential discrimination" is the 20th criteria of discrimination against individuals. ${ }^{2}$

France is an interesting case to study discrimination because the country ostensibly promotes a colorblind ideal of race relations (Sabbagh and Peer, 2008; Safi, 2008; Simon, 2008). For instance, the French Republican model forcefully rejects ethnicity, culture, and religion as a basis for political organization, claims-making, and even historically as the basis of categories for official statistics. Ethnicity per se is consequently not reported in any French public statistics survey. This makes it difficult for race-based affirmative action to be enforced and for inequality to be documented through representative data.

In this context, our article aims at analyzing the association between ethnic origin (specifically NorthAfrican background) and residential origin (coming from a deprived neighborhood) in a potentially discriminatory interaction in the housing market in France. Our goal is to explore how ethnic and residential stigma can be disentangled in the measurement of discrimination by analyzing practices and discourses about the overlap between these two criteria. To do so, we employ two methodological designs:

- An experimental paired-testing audit study, in the tradition of statistical analyses of discrimination, which aims to measure the interaction of ethnic and residential effects.

- A qualitative study, based on interviews with real estate agents who were asked open-ended questions about the selection process of housing applicants. ${ }^{3}$

\footnotetext{
${ }^{1}$ The link between racial and spatial stigma has been explored more frequently in qualitative research; see for instance Kirschenman and Neckerman (1991).

${ }^{2}$ It should be noted that residential location in deprived and segregated areas has also considerable legal socioeconomic consequences, well documented in the urban literature, undermining people's life chances in terms of education, health, employment, etc.

${ }^{3}$ The agents we interviewed are not necessarily the same as the agents we audited, and we will explain why this is not of
} 
Each method has its own advantages and limitations. While the audit study actually measures the role of the two criteria on discrimination, it does not address the mechanisms underlying ethnic and residential stigma. Conversely, face-to-face interviews provide discursive evidence on discrimination and describe its underlying micro social processes, but cannot assess discriminatory practices. Complementary use of both methods helps overcome their own specific shortcomings and, as a matter of fact, the juxtaposition of our audit and interview findings leads to a double paradox:

1. Although real estate agents believe ethnic discrimination to be widespread, it is not statistically significant in an audit study that controls for residential origin but is when residential origin is not controlled for.

2. Although real estate agents do not mention residential discrimination, it is statistically present in this audit study.

This article analyzes this discrepancy, highlighted in many studies of discrimination, between discourses and practices, and attempts to provide interpretations. We first review the research background and present our two sets of findings, then attempt to decode the double paradox that results. We then review alternative hypotheses that are consistent with these findings and may help us solve the paradox.

\section{The association between residence-based and ethnic discrimina- tion in housing: background and hypotheses}

\subsection{Space and ethnicity in discrimination studies}

There is now an extensive sociological and economic literature showing, through survey results, that residential location has significant effect on employment, education, crime, etc (Brueckner and Zenou, 2003; Fernandez and Su, 2004; Sampson and Sharkey, 2008). Despite this well documented role played by segregation and residential location in the production and perpetuating of inequality, the concept of "residential discrimination" has seldom been used and its effect rarely measured in audit studies on discrimination. Conversely, ethnic and racial discrimination in American cities has been measured with audit studies for more than three decades now (Committee on National Statistics, 2002, 2004; Fix and Struyk, 1993). These studies regularly document unequal treatment disadvantaging ethnic and racial minorities at various stage of the housing search process, both in the rental and ownership markets (Turner et al., 2013). The 2012 U.S. Department of Housing and Urban Development (HUD)'s study has in particular shown that Hispanics face higher levels of discrimination in the rental market (followed by Blacks and Asians); for example they learn about 12 percent fewer available housing units (compared to white housing applicants) when they contact real-estate agents to inquire about recently advertised units.

consequence. 
Comparisons of HUD's findings over time interestingly show that although "blatant" discrimination has declined - minority applicants are less likely to get the door slammed in their faces -, the overall level of discrimination remains high because of more subtle forms of discrimination. For instance minority applicants are more likely to be told that they must talk to a lender before being shown an advertised home for sale (whereas the white tester is able to meet with the agents without being asked about prequalification). This changing framing of discriminatory practices challenges the conventional measurement of discrimination in pair-testing studies and requires more attention to several details in the nature and quality of the interactions between the testers and the audited agencies or landlords.

Finally, in the majority of studies, measurements of ethnic and racial discrimination are interpreted as related to conscious motivations. This is corroborated by some findings on ethnic and racial neighborhood preferences highlighting whites' unwillingness to live in neighborhood with high proportion of ethnic minorities, particularly African Americans (Charles, 2009). In an audit similar to ours, Ahmed and Hammarstedt (2008) find that in the rental market male applicants with a Swedish name are much more likely to be called back than applicants with Arab names (with more mixed evidence for female applicants).

\subsection{Review of discrimination and immigration studies in the French context}

Similar studies are rare in France and research on ethnic segregation and discrimination in housing has only emerged recently. Most scholars have analyzed ethnic segregation as directly linked to "color blind" market mechanisms of social stratification. Recent studies challenge this, showing that ethnic segregation is of higher magnitude than socioeconomic segregation and that it decreases very slowly (Préteceille, 2009; Rathelot and Safi, 2014; Safi, 2009; Verdugo, 2011). French public statistics on housing also document considerable inequality between natives and immigrants. Such inequality occurs not only in housing access and tenure, but also in housing quality, such as amenities and apartment size (Barou, 2002; Breem, 2009). The immigrants' housing situation is particularly disadvantaged for non-Europeans and is resistant to standard socioeconomic controls, suggesting underlying ethnic discrimination. In a recent comprehensive survey on immigration and discrimination, first and second generation immigrants are shown to report twice more discrimination in housing access than natives with non-immigrant background (Safi and Simon, 2014). Here again, control for socioeconomic variables suggests that ethnic or racial discrimination may be, at least partly, at play. ${ }^{4}$ However, at present, there is almost no audit study based evidence of discrimination in the housing market in France. ${ }^{5}$

There is, however, well-established evidence of discrimination in the French labor market (Duguet et al., 2010; Duguet, L'Horty and Petit, 2011). One of the most comprehensive audit studies, conducted

\footnotetext{
${ }^{4}$ According to the same survey, the majority of respondents proposed their skin colon and/or their ethnic origin as discriminatory factors.

${ }^{5}$ The limited evidence of the extent of ethnic housing discrimination is from an audit study carried out by the Haute Autorité de Lutte contre les Discriminations et pour l'Egalité, according to which ethnic minority candidates (namely Africans) are four times less likely to be selected to rent an apartment compared to their paired French white candidates (HALDE, 2006).
} 
jointly by the ministry of labor and the International Labour Organization, shows that, four times out of five, employers prefer mainstream candidates to strictly identical candidates of African immigrant background (Cediey and Foroni, 2008). Research on ethnic discrimination in the labor market also provides evidence of "residential" discrimination. For instance, job applicants have lower interview rates when their curriculum vita provides an address indicating a poor suburb. The Cediey's and Foroni's audit findings also indicate that living in a poor suburb per se undermines employability. Their explanatory hypotheses draw on unobserved characteristics that employers may infer from the candidate's residential location (dependability, work ethic), or other observable contextual characteristics that may affect productivity (transportation connectivity to inner cities, crime, etc). Wasmer and Zenou (2002) provide a model of urban equilibrium unemployment where access to employment is negatively linked to distance between residential location and jobs due to information loss, employer's discrimination or connectivity of public transportation networks. Gobillon, Rupert and Wasmer (2014) find that spatial factors such as higher commute distance and poorer access to housing of minority workers can explain $20 \%$ of the ethnic unemployment gap in France and about $15 \%$ in the US. Statistical studies have also documented a significant effect of residential location on finding a job (Duguet, L'Horty and Sari, 2009; Gobillon, Magnac and Selod, 2011) and related these findings to the spatial mismatch literature. This research body raises the question of the existence of discrimination against residential origin in France and of the extent to which it may interact with ethnic discrimination.

France's emerging racial question is linked to the postcolonial nature of a considerable share of its immigration. While Europeans form the majority of first and second generation immigrants in France, the most recent waves increasingly come from ex-French colonies (Algeria, Morocco, Tunisia and subSaharan Africans mainly for francophone west Africa) (INSEE, 2012). There is growing empirical evidence that North-Africans (also referred to as Arabs or Maghrebi) and Sub-Saharan Africans are the most disadvantaged groups in regard to socio-economic and labour market attainment, residential segregation, law and justice, health, etc. (Meurs, Pailhé and Simon, 2006; Safi, 2013; Silberman, Alba and Fournier, 2007). The overwhelming majority of paired-testing audits conducted in France during the last decade hence use North or Sub-Saharan Africans as the potentially discriminated group. More recently, some studies focus on religious discrimination against Muslim origin (Adida, Laitin and Valfort, 2014). Although the first anti-discrimination law is rather old in France (it dates back to 1972), statelevel anti-discrimination action is traditionally weak and fragmented. In 2004, the French government created a centralized anti-discrimination agency (Haute Autorité de Lutte contre les Discriminations et pour l'Egalité) in a context of growing consciousness related to discrimination in the political and scientific debates. The HALDE was however dismantled in 2011 and specific action towards racial and ethnic discrimination has been increasingly reframed into a more general diversity promoting discourse (Bereni and Jaunait, 2009; Doytcheva, 2010). 


\subsection{In the search of "residential discrimination" in the housing market: disen- tangling residential and ethnic effects}

The majority of testing studies draws on Becker (1971)'s and Phelps (1972)'s frameworks of taste and statistical discrimination, and are designed to empirically disentangle the underlying processes. In the housing market in particular, statistical discrimination is tested for by adding information in the applicant's profile (see for instance Bosch, Carnero and Farre, 2010; Ewens, Tomlin and Wang, 2014). These studies nevertheless only frame one criterion as being potentially discriminatory (namely ethnic/racial or immigrant background) while other added information is not regarded as possibly brining about unequal treatment. Our study thus adds to this literature by reflecting on the association between two potentially discriminatory criteria that may affect housing outcomes. More precisely, we seek to test for three hypotheses:

- Hypothesis one (H1): Real estate agents are primarily concerned with insolvency and they use any potentially relevant information about the applicants as proxies to make inferences about their unobserved solvency. In other words, ethnic and residential origins may lead to statistical discrimination in a context of high legal constraints in the French housing market that increase landlords' incentives to economically select tenants.

- Hypothesis two (H2): ethnic discrimination and residential discrimination both exist and are combined through an additive effect on overall discrimination, with no particular interaction. If this is the case, real estate agents would engage in pure discrimination against a given type of neighborhood. This would be an instance of taste discrimination against a neighborhood. $\mathrm{H} 2$ thus consists of a cumulated pure-taste discrimination hypothesis.

- Hypothesis three (H3): the neighborhood does not matter per se: agents merely use the information about the neighborhood to infer applicant's race or ethnicity. What appears as discrimination against a neighborhood is in fact discrimination against racial or ethnic minorities. Legal scholars call this indirect discrimination (Hunter, 1992): the use of legally unprotected characteristics to achieve legally forbidden discrimination.

Our research design aims to examine these three different hypotheses, not necessarily exclusive from each other, disentangling ethnic and residential stigma in the measurement of discrimination.

\section{Research design: the complementary use of qualitative and quan- titative frameworks}

Direct accounts of discrimination in the social sciences usually fall into two categories (Blank, Dabady and Citro, 2004; Pager and Shepherd, 2008): 
- Analyses of discriminatory attitudes, behaviors and discourses: studies that focus on the mental and social constructions of prejudice and the micro social processes that may lead to discriminatory acts (Fiske, 2000; Schuman et al., 1997).

- Measurements of discriminatory practices: studies that seek to uncover actual discrimination as "a caught in the act" through experimental situations in order to measure its magnitude, evolution and consequences (Fix and Struyk, 1993; Pager, 2007) following standard procedures of the HUD described in Appendix A.1.

Only a few studies mobilize both qualitative and quantitative methodologies. These have led to contradictory results, showing that what people say or think with regard discrimination is not coherent with what they really do. This was the main finding of LaPiere (1934) classic study of discrimination in hotels (people discriminate less than they express prejudice). More recently, Pager and Quillian (2005) have conducted a similar study that shows an opposite discrepancy between attitudes and actions (people discriminate more than they exhibit prejudice). In both cases, the authors' interpretations are inclined to trust the experimental measurement of discrimination acts whereas people's attitudes are often regarded as doubtful. ${ }^{6}$ The two methodologies of inquiring into discrimination are thus presented as concurrent rather than complementary.

In this article, we first use an audit testing strategy to explore the association between residential and ethnic effects, then we conduct a qualitative survey to assess the prevalence of ethnic or/and residential stigma and how these stigma may affect real estate agents' decision with regard tenants' selection. It should be noted that, unlike other studies that combine testing methods with qualitative interviews while measuring discrimination, our qualitative and quantitative samples are not matched (LaPiere, 1934; Pager and Quillian, 2005). We thus do not audit people we interview. We believe that this is not of consequence to our argument because we constructed our sample of respondents for the qualitative study and of agencies for our audit study on the same principles: just as we selected richer and poorer neighborhoods in Paris and its region where we audited agencies, we contacted interview respondents in richer and poorer neighborhoods in Paris and its region advertising the same type of goods advertised by the audited agencies.

\section{Measuring the intersection between ethnic and residential dis- crimination factors: an audit study on the Parisian rental market}

\subsection{The audit study ${ }^{7}$}

Our audit study was carried out in March and April 2009. A team of 8, aged 22 to 28, 2 women and 6 men (hereafter the "testers") made a total of 500 phone calls to real estate agencies for 250 different

\footnotetext{
${ }^{6}$ Economists call this a logic of revealed preferences, after Samuelson (1938).

${ }^{7} \mathrm{~A}$ comprehensive description of our audit study is in Appendix A.
} 
housing vacancies in the Paris region. We collected advertisements for housing units from the website http: //www. seloger.com, the first internet platform at the time of the study.

The test was designed to detect the effect of two potentially discriminatory criteria: current place of residence (deprived neighborhood) of the fictitious applicant, and ethnic origin (North-African background), as revealed by the name. Testers were matched by pairs: each tester thus had a co-tester he/she worked with most of the time. They were instructed not to fake any particular acccent during the phone conversations. ${ }^{8}$ Testers were assigned fictitious identities, which included a name, a place of residence, an occupation and an income level. These were designed to reflect a typical middle-class housing applicant, for instance: "Sébastien Fournier (French name) / Kader Boualem (North African name), lives in La Courneuve (deprived suburb) / Versailles (rich suburb), is 31 years-old, works as an accountant and earns a monthly wage of 1,700 euros". These fictitious identities also included a marital status (married with no children), an occupation and an income for the spouse.

As it was neither possible to test all the combinations between geographic and ethnic origins on the same advertised dwelling nor to reveal all the relevant information within a phone conversation, we limited the number of scenarios and designed two different procedures:

- In the first procedure (173 audits), each tester revealed his/her fictitious place of residence at the beginning of the conversation and, as the conversation proceeded, he/she eventually gave his/her name.

- The second procedure (77 audits) was similar but reversed: the fictitious name was revealed first, with the tester attempting to provide information on his/her current location, without forcing matters.

The phone conversations that resulted from these procedures were usually as follows: in the very first sentence, the tester expressed his/her interest for the advertised dwelling. Here are examples of the introductory sentences testers would use:

- In procedure \#1: "Hello, I'm calling about your ad for the apartment located in city X. I'm really interested in renting this apartment since I need to move from city of the applicant where I currently live to get closer to my job. Is it still available?"

- In procedure \#2: "Hello, name of the applicant speaking. I'm calling about your ad no. X found on the internet. I'm really interested in the apartment in the ad because I need to move to get closer to my job. Is this still available?"

The typical conversation would then go on as follows:

\footnotetext{
${ }^{8}$ This rule reflected a trade-off: introducing accent would have increased unobserved heterogeneity (arbitrariness and thus randomness) in the perception interpretations. Preventing accents likely biased downwards the intensity of discrimination. See Section A.4 of Appendix A for further discussions.
} 
- If the apartment was still available, the applicant would then ask for an appointment to view the apartment. The rental broker would eventually ask for more information about the applicant, and the tester attempted to provide his/her name (procedure \#1) or his/her place of residence (procedure \#2).

- If the apartment was no longer available, the rental broker would generally ask some additional details to determine whether another apartment might meet the applicant's demand, or would terminate the conversation quickly.

The resulting phone conversations were thus short, focusing on the candidate's profile and homogenous across testers and procedures. In all cases, the testers could collect information about the rent, the surface area and the location of the apartment from the advertisement on the Internet.

Following the phone call, testers reported the outcomes of the conversation, which were coded as follows:

\begin{tabular}{cl} 
Code & Outcome \\
\hline 1 & Apartment is already rented, nothing else available \\
2 & Caller is asked to send a written application with personal details \\
3 & Real estate agent will call back, but no return call \\
4 & Apartment is already rented but something else is available \\
5 & Real estate agent plans a group visit \\
6 & Real estate agent plans an individual visit
\end{tabular}

These coding schemes were the outcome of several days of trials on about 50 calls (which are not included in our sample of audits). Overall, they proved sufficiently comprehensive for testers to report the outcomes of the different phone conversations without being concerned that a relevant category was missing.

\subsection{Outcomes of the phone conversations}

Figure 1 compares the distribution of outcomes of the phone conversations obtained under the two procedures, initially ignoring the paired-testing dimension of the experiment, pooling all applicants. Those reveal similarities, suggesting that differences in the introductory sentence used by testers did not significantly alter the interaction with the rental agent. In other words, in both procedures, the fictitious applicants were able to arrange an individual viewing with the rental broker most of the time (35 to $40 \%$ of all phone calls), and they were also likely to be told that the rental agent would call them back ( 32 and $35 \%$ of all phone calls). 


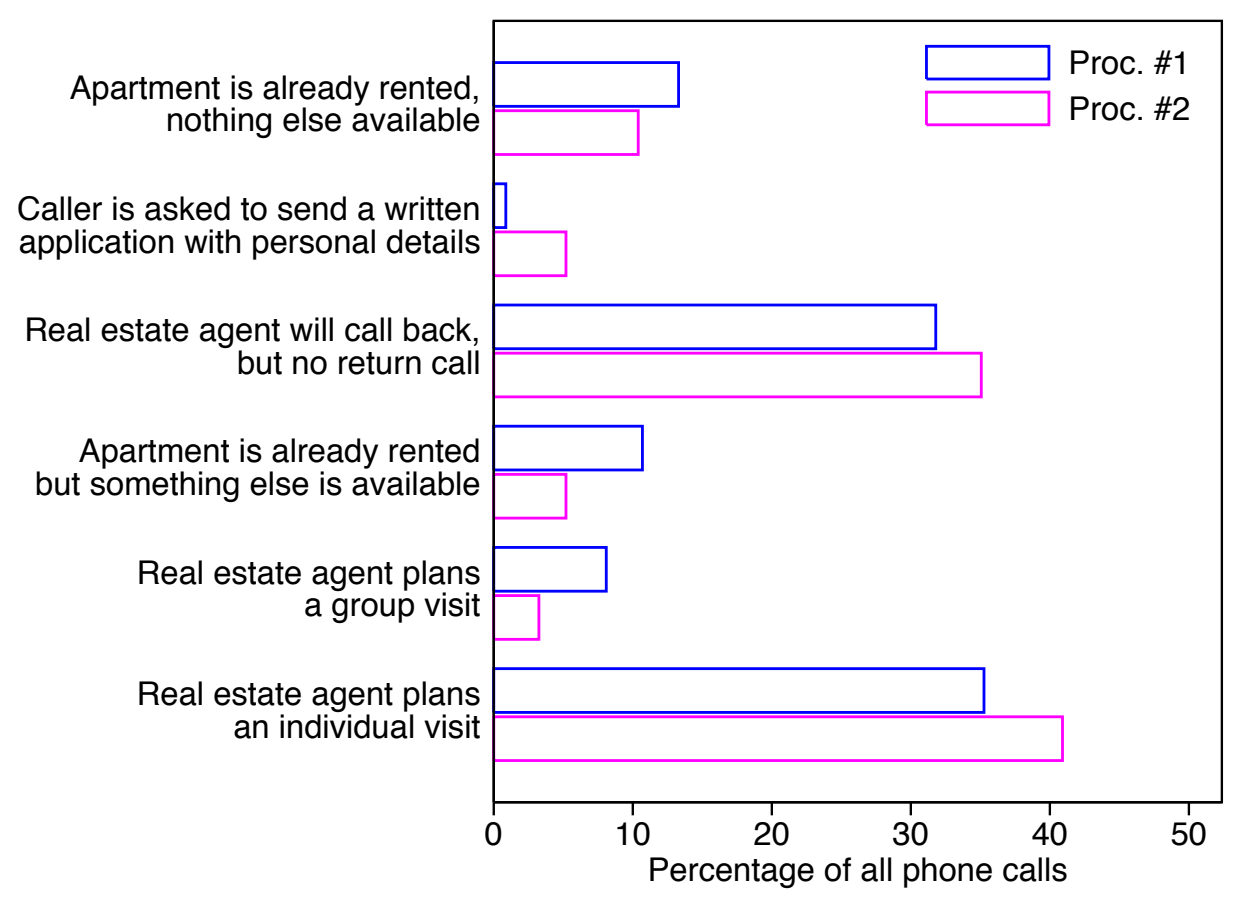

Figure 1. Outcomes of the phone conversations

NOTE: The figure represents in percentage the different possible outcomes of the phone conversations, under the first and the second procedure (residence revealed first and ethnicity revealed first, respectively). All applications are pooled together.

\subsection{Detecting discrimination: differences in outcomes across paired phone con- versations}

To simplify the presentation of the results, we group occurrences 1, 2 and 3 as "negative answers" and 4, 5 and 6 as "positive answers". 9 We use the term "minority candidate" to refer to the applicant from the deprived suburb in the first procedure and to the applicant with a North African name in the second procedure. Note that the minority candidate in, for instance, the second procedure may have been assigned a fictitious residence in a privileged suburb: the term "minority" refers only to the information revealed first during the conversation. Accordingly, the paired-tester is labeled the "majority candidate".

In Table 1, we crosstabulate the outcomes of the two candidates obtained under each procedure (residence first, or ethnicity first). The full results are displayed in Tables B1 and B2 of Appendix B. In each panel, the first number is the number of cases and the second number is the frequency in the table, i.e. the number of cases divided by the total number of cases studied. The on-diagonal coefficients report the number of cases where the minority and the majority candidates were equally treated, at least when

\footnotetext{
${ }^{9}$ As rightly noticed by a referee, Code 4 (advertised unit was unavailable but "something else" was offered) could alternatively be interpreted either as "some discrimination" or "steering", and therefore be aggregated with codes 1, 2 and 3 ("rather negative outcome"). Since there were few occurrence of this outcome (Figure 1), we adopt as a benchmark the aggregation of Code 4 with Codes 5 and 6 (rather favorable). In Appendix B, we repeat our estimations after aggregating Code 4 with Codes 1 to 3. We also re-run our estimations after excluding applications involving occurrence of Code 4 . None of these checks alter the findings presented in this Section.
} 
Table 1. Cross-tabulation of the outcomes across paired phone calls

\begin{tabular}{|c|c|c|c|}
\hline \multirow[t]{2}{*}{ a. Procedure \#1 (residence first) } & \multicolumn{2}{|c|}{ Outcome of the minority candidate } & \multirow[b]{2}{*}{ Total } \\
\hline & Rather negative $(1,2,3)$ & Rather positive $(4,5,6)$ & \\
\hline \multicolumn{4}{|l|}{ Outcome of the majority candidate } \\
\hline Rather negative $(1,2,3)$ & $46(26.6 \%)$ & $24(13.9 \%)$ & $70(40.5 \%)$ \\
\hline Rather positive $(4,5,6)$ & $43(24.9 \%)$ & $60(34.7 \%)$ & $103(59.5 \%)$ \\
\hline Total & $89(51.5 \%)$ & $84(48.6 \%)$ & 173 \\
\hline \multirow[t]{2}{*}{ b. Procedure \#2 (ethnicity first) } & \multicolumn{2}{|c|}{ Outcome of the minority candidate } & \\
\hline & Rather negative $(1,2,3)$ & Rather positive $(4,5,6)$ & Total \\
\hline \multicolumn{4}{|l|}{ Outcome of the majority candidate } \\
\hline Rather negative $(1,2,3)$ & $30(39.0 \%)$ & $11(14.3 \%)$ & $41(53.3 \%)$ \\
\hline Rather positive $(4,5,6)$ & $7(9.1 \%)$ & $29(37.7 \%)$ & $36(46.8 \%)$ \\
\hline Total & $37(48.1 \%)$ & $40(52.0 \%)$ & 77 \\
\hline
\end{tabular}

grouping the different outcomes. For instance in the first procedure (panel a.) this occurred in 26.6\% $+34.7 \%=61.3 \%$ of all cases. The off-diagonal coefficients report unequal treatment, in the remaining $38.7 \%$ of cases. The upper-right cell reports cases where the minority candidates were better treated than the majority candidate, which occurred in just $13.9 \%$ of cases. In contrast, the lower left cell reports cases where the majority candidate was treated better than the minority candidate. This occurred in $24.9 \%$ of cases.

In the second experience, where ethnicity was revealed first (panel b.), discrimination appears to be much less important. In fact, the on-diagonal cases now constitute $76.7 \%$ of cases, the fraction of cases in which the minority and the majority candidates are equally treated.

The off-diagonal coefficients reporting an unequal treatment reveal that the minority candidates was better treated than the majority candidate in $14.3 \%$ of cases, while the majority candidate was actually better treated in $9.1 \%$ of cases, that is, in fewer cases.

We can summarize the information in Table 1 by computing the discrimination rates displayed in Table 2.

Table 2. Discrimination rates under the two procedures

\begin{tabular}{ccc}
\hline & Procedure \#1 (residence first) & Procedure \#2 (ethnicity first) \\
\hline$N_{M} / N$ & $24.86 \%[18.42 \%, 31.30 \%]$ & $9.10 \%[2.67 \%, 15.51 \%]$ \\
$N_{m} / N$ & $13.87 \%[8.72 \%, 19.02 \%]$ & $14.29 \%[6.47 \%, 22.10 \%]$ \\
$z$-statistic & 2.585 & -1.003 \\
$p$-value & 0.0097 & 0.3157
\end{tabular}

NoTE: $N_{M}$ (resp. $N_{m}$ ) denotes the number of audits in which majority (resp. minority) candidate obtains a positive outcome while the minority candidate (resp. majority) does not. Numbers in brackets are $95 \%$ confidence intervals. The $p$-value is associated to the null hypothesis that the relative difference $N_{M}-N_{m} / N$ is significantly different from 0 .

These discrimination rates confirm that the candidate from the deprived suburb was significantly less 
likely to have a positive response in the first procedure relative to his/her paired applicant, while there was no significant evidence of a similar treatment against the candidate with a North African name in the second procedure (or even the opposite here). The next subsection examines the robustness of these first results and, as it happens, consolidates them.

\subsection{Robust assessment of the presence of discrimination}

We test different specifications that take advantage of the panel structure of our dataset to analyze whether the phone conversations indicate discrimination against minority candidates. These specifications are variants of a linear probability model that accounts for the probability of obtaining a positive outcome. The generic model that we consider is:

$$
y_{i, a}=z_{a}+\gamma d_{i, a}+\beta X_{i, a}+\varepsilon_{i, a}
$$

where $y_{i, a}$ is an indicator taking the value of one if applicant $i$ obtains a favorable outcome in audit $a$, $z_{a}$ is a set of variables that characterize the paired audit, $d_{i, a}$ is a dummy with the value of one if the applicant is the minority candidate, and $X_{i, a}$ is a set of controls that characterizes tester $i$ in audit $a$. In the baseline model, $z_{a}$ includes some characteristics of the advertised dwelling, such as the surface, the rent, etc. Next, we drop these in favor of audit fixed effects. Tables $3 a$ and $3 b$ reports the results from these different regressions.

The regressions in Tables $3 \mathrm{a}$ and $3 \mathrm{~b}$ confirm the rough calculations from Table 2: the applicant from the deprived suburb in the first procedure (residence first) experiences a more than 10 percentage point drop in the probability of obtaining a favorable outcome. The coefficient is precisely estimated and robust to the set of controls included in the regression. Interestingly, there is no evidence of a less favorable treatment for the minority candidate in the second procedure: having an Arab name has no significant impact on the probability of obtaining a viewing.

In the first procedure (residence first), further revealing the name led to a significantly higher outcome, regardless of the ethnicity of the name. This may be a simple statistical association and not a causal one: this occurred only when the candidate was able to arrange a meeting for the viewing, i.e. when a positive outcome had been obtained. The North African origin of the name is negative but not significant or very marginally in columns (VI) and (VII). In terms of the other potentially discriminatory criterion (North African name in the first procedure, deprived suburb in the second procedure), we find no significant impact when this was revealed to the rental agent. This could be because we have fewer observations in the second procedure, affecting the significance of the coefficients. To verify that this is not the case, we replicated the regression with a bootstrap procedure (500 times) randomly selecting 77 pairs of calls from the first procedure among the 177 initial pairs. The full results, reported in Table B3 of Appendix B,

reveal that the conclusions above still hold: the negative effect of living in a deprived suburb remains true in all columns. The significance level is reduced: it is now at the $10 \%$ level in 4 out of 7 specifications, 
Table 3a. Estimation results: Procedure \#1 (residence first)

\begin{tabular}{lccccccc}
\hline & (I) & (II) & (III) & (IV) & (V) & (VI) & (VII) \\
\hline & & & & & & & \\
Deprived suburb & $\mathbf{- 0 . 1 4 4 0}$ & $\mathbf{- 0 . 1 3 8 7}$ & $\mathbf{- 0 . 1 3 8 7}$ & $\mathbf{- 0 . 1 0 9 8}$ & $\mathbf{- 0 . 1 2 2 7}$ & $\mathbf{- 0 . 1 3 0 1}$ & $\mathbf{- 0 . 1 3 7 3}$ \\
& $(0.0638)$ & $(0.0564)$ & $(0.0564)$ & $(0.0468)$ & $(0.0480)$ & $(0.0522)$ & $(0.0520)$ \\
Minority name & 0.0567 & 0.0152 & 0.0152 & & & 0.1273 & 0.1046 \\
$\quad$ North Africa) & $(0.1110)$ & $(0.1004)$ & $(0.1004)$ & & & $(0.0924)$ & $(0.0939)$ \\
Name revealed & $\mathbf{0 . 2 4 3 1}$ & $\mathbf{0 . 1 7 8 8}$ & $\mathbf{0 . 1 7 8 8}$ & & & $\mathbf{0 . 2 4 1 5}$ & $\mathbf{0 . 2 3 7 3}$ \\
& $(0.0987)$ & $(0.0833)$ & $(0.0833)$ & & & $(0.0997)$ & $(0.1009)$ \\
Name revealed & -0.0932 & 0.0110 & 0.0110 & & & -0.1888 & -0.1747 \\
$\quad$ X Minority Name & $(0.1276)$ & $(0.1123)$ & $(0.1123)$ & & & $(0.1175)$ & $(0.1161)$ \\
\hline Controls: & & & & & & & \\
$\quad$ Individual call & $\mathrm{Y}$ & $\mathrm{Y}$ & $\mathrm{Y}$ & & $\mathrm{Y}$ & & $\mathrm{Y}$ \\
$\quad$ Vacancy characteristics & $\mathrm{Y}$ & $\mathrm{Y}$ & $\mathrm{Y}$ & & & & \\
$\quad$ City level dummies & $\mathrm{Y}$ & & $\mathrm{Y}$ & & & & \\
Fixed effects & & & & & & & $\mathrm{Y}$ \\
$\quad$ Audit level & & & & $\mathrm{Y}$ & $\mathrm{Y}$ & $\mathrm{Y}$ & $\mathrm{Y}$ \\
Pairs of testers & $\mathrm{Y}$ & & $\mathrm{Y}$ & & & & \\
$\quad$ Individual testers & & $\mathrm{Y}$ & $\mathrm{Y}$ & & & & \\
\hline$N$ & 327 & 327 & 327 & 346 & 346 & 345 & 345 \\
$R^{2}$ & 0.7371 & 0.5972 & 0.5972 & 0.0311 & 0.0443 & 0.0668 & 0.0775 \\
$R^{2}$ with fixed effect & & & & 0.8264 & 0.8288 & 0.8352 & 0.8370 \\
\hline
\end{tabular}

NotE: Estimates that are statistically significant at the $5 \%$ level are in boldface. Standard errors in parentheses. Standard errors are clustered at the audit level. Each column reports the coefficients $\gamma$ and $\beta$ estimated along with a specific set of controls for each procedure. Name revealed is a dummy indicating whether the tester revealed his/her name in the phone conversation. Characteristics at the level of the individual phone calls are: a dummy indicating whether the tester used the phone line with a number starting with 09 (indicating Internet box) and a dummy indicating whether he/she called first. Vacancy characteristics include the rent and the surface of the advertised dwelling. City level dummies are dummies at the level of the city when the dwelling is located outside of Paris or, otherwise, at the level of arrondissements.

and marginally less significant in the other three specifications. ${ }^{10}$

\section{4 “Whom you discriminate against?” Asking real estate agents}

The qualitative part of this paper was designed to confirm, or at least verify, whether the surprising result of the audit testing strategy would be perceived by agents themselves, and whether they would be conscious of the apparent importance of residence in the outcome. It however tells a different story, and, incidentally, shows the importance of confronting different methodologies.

\footnotetext{
${ }^{10}$ This result is not surprising in the first procedure given that procedure \#2 shows that having a North African name does not play against the minority candidate. Conversely, why living in a deprived area has no significant impact in the second procedure may seem puzzling given the robust effect obtained during procedure 1 . This may be due to the small number of phone calls in the second procedure during which the applicant from the deprived suburb managed to reveal this information to the rental agent: 16 cases out of the 154 phone calls.
} 
Table 3b. Estimation results: Procedure \#2 (ethnicity first)

\begin{tabular}{|c|c|c|c|c|c|c|c|}
\hline & (I) & (II) & (III) & (IV) & (V) & $(\mathrm{VI})$ & (VII) \\
\hline Minority name & $\begin{array}{c}0.0299 \\
(0.0785)\end{array}$ & $\begin{array}{l}-0.1076 \\
(0.1776)\end{array}$ & $\begin{array}{l}-0.1118 \\
(0.1984)\end{array}$ & $\begin{array}{c}0.0519 \\
(0.0553)\end{array}$ & $\begin{array}{c}0.0484 \\
(0.0604)\end{array}$ & $\begin{array}{c}0.0502 \\
(0.0624)\end{array}$ & $\begin{array}{r}0.0419 \\
(0.0728)\end{array}$ \\
\hline Deprived suburb & $\begin{array}{c}0.0468 \\
(0.0821)\end{array}$ & $\begin{array}{c}0.0481 \\
(0.0768)\end{array}$ & $\begin{array}{c}0.0768 \\
(0.0765)\end{array}$ & & & $\begin{array}{c}0.0261 \\
(0.0706)\end{array}$ & $\begin{array}{r}0.0298 \\
(0.0715)\end{array}$ \\
\hline Residence revealed & $\begin{array}{c}0.1001 \\
(0.2553)\end{array}$ & $\begin{array}{c}0.3255 \\
(0.2494)\end{array}$ & $\begin{array}{c}0.2365 \\
(0.2499)\end{array}$ & & & $\begin{array}{c}0.0686 \\
(0.2213)\end{array}$ & $\begin{array}{r}0.1148 \\
(0.2578)\end{array}$ \\
\hline $\begin{array}{l}\text { Residence revealed } \\
\text { x Deprived suburb }\end{array}$ & $\begin{array}{l}-0.2307 \\
(0.2713)\end{array}$ & $\begin{array}{l}-0.3588 \\
(0.2887)\end{array}$ & $\begin{array}{l}-0.4082 \\
(0.3109) \\
\end{array}$ & & & $\begin{array}{l}-0.1434 \\
(0.2361)\end{array}$ & $\begin{array}{l}-0.1837 \\
(0.2742) \\
\end{array}$ \\
\hline Controls: & & & & & & & \\
\hline Individual call & $\mathrm{Y}$ & $\mathrm{Y}$ & $\mathrm{Y}$ & & $\mathrm{Y}$ & & $\mathrm{Y}$ \\
\hline $\begin{array}{l}\text { Vacancy characteristics } \\
\text { City level dummies }\end{array}$ & $\begin{array}{l}\mathrm{Y} \\
\mathrm{Y}\end{array}$ & $\mathrm{Y}$ & $\begin{array}{l}\mathrm{Y} \\
\mathrm{Y}\end{array}$ & & & & \\
\hline Fixed effects & & & & & & & \\
\hline $\begin{array}{l}\text { Audit level } \\
\text { Pairs of testers } \\
\text { Individual testers }\end{array}$ & $\mathrm{Y}$ & $\mathrm{Y}$ & $\begin{array}{l}\mathrm{Y} \\
\mathrm{Y}\end{array}$ & $\mathrm{Y}$ & $\mathrm{Y}$ & $\mathrm{Y}$ & $\mathrm{Y}$ \\
\hline$N$ & 144 & 144 & 144 & 154 & 154 & 154 & 154 \\
\hline $\begin{array}{l}R^{2} \\
R^{2} \text { with fixed effect }\end{array}$ & 0.6295 & 0.5789 & 0.6358 & $\begin{array}{l}0.0115 \\
0.8771\end{array}$ & $\begin{array}{l}0.0194 \\
0.8787\end{array}$ & $\begin{array}{l}0.0191 \\
0.8780\end{array}$ & $\begin{array}{l}0.0305 \\
0.8801\end{array}$ \\
\hline
\end{tabular}

NOTE: Standard errors in parentheses. Standard errors are clustered at the audit level. Each column reports the coefficients $\gamma$ and $\beta$ estimated along with a specific set of controls for each procedure. Residence revealed is a dummy indicating whether the tester revealed his/her residential origin in the phone conversation. Characteristics at the level of the individual phone calls are: a dummy indicating whether the tester used the phone line with a number starting with 09 (indicating Internet box) and a dummy indicating whether he/she called first. Vacancy characteristics include the rent and the surface of the advertised dwelling. City level dummies are dummies at the level of the city when the dwelling is located outside of Paris or, otherwise, at the level of arrondissements.

\subsection{Interviewing real estate agents}

This involved 29 face-to-face semi-directive interviews with real estate agents in Paris and the surrounding Parisian region, conducted between June and October 2010. Each interview lasted at least one hour. ${ }^{11}$

These interviews firstly reveal that, while the overwhelming majority of agents tend to deny any form of discrimination in their own decisions, they have a lot to say about the functioning of the market in general and about other agencies' discriminatory actions in particular.

\subsection{Ethnic and racial discrimination is everywhere... but not here!}

Perhaps unexpectedly, interviewees felt comfortable talking about discrimination, without us expressly mentioning of the term. As soon as the section about the "ideal candidate" begins, the word "discrimination" arose naturally in the discussion, and was systematically associated with ethnic or racial dimensions.

\footnotetext{
${ }^{11}$ For more information about the interviews, please refer to Appendix C.
} 
The issue of ethnic or racial discrimination was spontaneously raised by 13 interviewees (out of 29) without any overt questioning by the interviewer. In all these cases, discrimination was directly associated to ethnic and racial criteria, with skin color (or African origin) most cited.

Table 4 shows the recurrence of words referring to ethnic/racial criteria, distinguishing whether they were used by the interviewees or the interviewers. Interviewer and respondent used the word "origin" with equal frequency, whereas words indicative of ethnicity were predominantly used by interviewees. On average, the words reported in Table 4 are used more than twice as frequently by the interviewee.

Table 4. Recurrence of words referring to ethnic/racial criteria in the interviews

\begin{tabular}{lccc}
\hline & Respondent & Interviewer & Ratio \\
\hline \hline Turk(s) & 23 & 2 & 11.5 \\
Africa, African, etc. & 36 & 4 & 9.0 \\
Black(s) & 105 & 20 & 5.3 \\
\hline Arab(s) & 26 & 6 & 4.3 \\
White(s) & 37 & 11 & 3.4 \\
Race, racial & 14 & 7 & 2.0 \\
\hline Racist, racism & 45 & 23 & 2.0 \\
Foreigner(s) & 45 & 29 & 1.6 \\
Origin & 52 & 56 & 0.9 \\
Ethnic, ethnicity & 19 & 26 & 0.7 \\
\hline Total & 402 & 184 & 2.2 \\
Total per interview & 13.9 & 6.3 & 2.2 \\
\hline
\end{tabular}

Even though real estate agents spoke extensively about ethnic and racial discrimination, they systematically denounced it as "bad" and "illegal" and denied the existence of such practices in their own agency.

Well I have people, blacks, who came to the agency and they told me, err... So I welcomed them and they told me: "we just got sent on our way by - well, I won't tell their name, an agency not far from here [he laughs] and err... they've been told: "No, no Sir, we have nothing to rent". They had just arrived, and they were told: "we have nothing to rent".

They most frequently blamed the landlords for pushing real estate agents into discriminating against minorities, but said that whenever they had to deal with such landlords, they refused to comply. Besides the fact that all testimonies converge on the salience of discrimination against black and Arab minorities, some real estate agents provide the interviewer with objective figures quantifying such practices, saying that almost $10 \%$ of renting offers come with discriminatory recommendations from landlords ("I don't want Arabs, blacks, etc.").

- Do you have a recent experience of verbal complaint?

- Yeah, it happened maybe one year ago: someone went to complain to the person in charge of rentals. 
- What do you say in those situations?

- Well, we tell them: we have presented the application to the landlord, and the landlord decides. We can't do anything about it. Because if we really did refuse that kind of persons, according to me we are all persons, no matter the color, we are all human beings, therefore this a behavior that makes me mad. If the person is working, I don't see where there is a problem. We can see the kind of people we're dealing with. Now we can't force landlords. But us, we won't refuse viewings to these people.

- And if you had to assess the percentage of racist demands?

- Yes, you can say that. It's not the majority, but not matter how small... I don't know, 10\%?

Real estate agents often imply that they understand the landlords' aversion to certain profiles who have proved by experience to be unreliable (e.g. unpaid rent, sublease, damage). This argument builds even more explicitly on statistical discrimination.

The landlord asks us to avoid certain categories of population. We don't have the right. We can't do racism like that. Otherwise, we would only get into big trouble. But, it is true that... Experience is such that we avoid certain categories of people because we realize that in these categories we always have problems.

Let's say that experience is that... we will be more careful with certain categories than with others.

In short, when asked about the selection of applicants for housing rentals, real estate agents find racial discrimination the obvious issue. However, they overtly condemn racial discrimination, describe it as a landlords' problem, not one of the real estate business itself. Some agents display understanding attitudes toward forms of discrimination they find rational, other agents find the practice of discriminating on racial grounds economically irrational. But they all see racial discrimination as the issue at stake.

\subsection{Looking for residence-based discrimination}

In stark contrast, none of the respondents spontaneously mentioned residential stigma. The interview was planned so that the interviewer asked this question at the end of the conversation, after a lot of developments on discriminatory practices and their motivations. The question was formulated thus: "There is much debate about ethnic and racial discrimination but do you think that other criteria might be at play, for example residential ones?", "If a candidates comes from underprivileged neighborhood, the suburbs, etc. do you think this may disadvantage him/her in the renting market?"

This question was disconcerting to most real estate agents. An overwhelming majority could simply not see why residence might have any impact. Almost all respondents said that they do not care where a candidate lived. Some of them even assert that they rarely check the address when they examine the candidate, or that they would not know in what kind of neighborhood a given address is located. Only 
two respondents elaborated on this question, mentioning association with linguistic stigma: according to them, the problem is not the area of residence itself, but the fact that people from these neighborhoods do "not express themselves well" or have particular "accent". Only one single respondent admitted that some locations (and he/she cited the most stigmatized French suburbs) can disadvantage candidates even though he gave an example of labor market discrimination, not housing.

\section{The paradox: a discussion}

The confrontation of our audit and interview findings leads to a double paradox:

1. Real estate agents clearly deny the relevance of residence as a discriminatory factor in the housing market while quantitative evidence tends to show that it has a significant disadvantaging effect in access to housing.

2. Ethnic origin does not have a significant impact when the area of residence is controlled for in the exploitation of the audit study data, while real estate agents report that it has an indisputable discriminatory impact.

Thus, the widespread ethnic discrimination identified by real estate agents is not statistically significant in the audit study that controls for residence, while residential discrimination, which is not seen as important by real estate agents, is statistically significant in the same study.

The qualitative interviews lead to the elimination of one of the three hypotheses developed in Section 1.3 , that there might be something like pure discrimination against a type of area of residence. The real estate agents we interviewed never mentioned this, either directly or indirectly. ${ }^{12}$ Furthermore, there is no reason to assume that this might be an effect of a social desirability bias, as real estate agents are not shy about documenting racial discrimination, which is more controversial. We now discuss whether the remaining two hypotheses (hypotheses $\mathrm{H} 1$ and $\mathrm{H} 3$ ) are consistent with the double paradox revealed above.

\section{Discussion of H1: "statistical discrimination through proxying applicants' solvency"}

The first hypothesis is that real estate agents are primarily concerned with insolvency and that any correlates with insolvency (including residential or ethnic origins) may lead to biases in tenants selection through mechanisms of statistical discrimination (i.e. the combination of information about ethnicity and residence interacts in signaling low socio-economic background, which translates into a marker of greater likelihood of insolvency, leading real estate agents to select against these applicants). This hypothesis is in line with former studies highlighting that the French housing market legal framework may be overly

\footnotetext{
${ }^{12}$ One may suspect this result to be biased since real estate agents may have denied the existence of residential discrimination in order to be clear about them not admitting any type of illegal bias. However, at the time of the interviews, only racial discrimination was both illegal and subject to testing by associations. Such was not the case of residential discrimination.
} 
protective of tenants, ${ }^{13}$ which leads to increasing landlords' concerns about potential problems of default of payment on the rent. ${ }^{14}$

This hypothesis may appear to be consistent with the double paradox and it is also in line with a prevailing political and scientific belief that, unlike the American context, ethnicity and race are less prominent inequality factors in France (Wacquant, 2008). In other words, the nonsignificant effect of ethnicity when residential origin is controlled for can be read as a demonstration of the supremacy of class over race in generating social inequality in France reducing thus the disadvantage experienced by ethnic minorities to socio-economic and "color-blind" factors. Within this framework, the double paradox in our findings is no more a paradox but could be interpreted as evidence that residential location is used as a proxy for insolvency or "bad tenant" (and not for "race") and that real estate agents perceive white applicants from bad neighborhoods as bad as minority applicants from bad neighborhoods.

If this interpretation may be appealing, it should be noted that it is not directly established by our findings but rather stems from a speculative explanation buildings on prior studies on the legal French housing market environment. It nonetheless may appear to be in contradiction with growing empirical evidence on ethnic and racial inequality in France documented in diverse social spheres (labor and housing markets, schooling and education, spatial segregation, health, access to law and public services, etc.). In fact, the contradiction is not so straightforward because hypothesis 1 could also be read in line with the sociological concept of systemic or indirect discrimination (Bonilla-Silva, 2013): the legal structure of the housing market in France could lead to systematic ethnic bias although its driving mechanisms may not be directly oriented toward ethnic minorities. All in all, if residential origin is a powerful proxy for insolvency, it indirectly undermines ethnic minority chances in the rental market simply because ethnic minorities are highly concentrated in these disadvantaged neighborhoods.

\section{Discussion of H3: "neighborhood as a proxy for ethnicity"}

The other hypothesis is that residential stigma proxies ethnic stigma. Ethnicity would thus be the signal that affects real estate agents' decisions when selecting among applicants and information about place of residence is used to proxy ethnic origin. Moreover, even if residential origin is translated into ethnic origin in real estate agents' minds, it may be more conducive to discriminatory decisions than overt information about ethnic origin (like for instance an African name) because of a less pronounced desirability bias of residential discrimination. This may explain the fact that, in our data, the negative impact of ethnicity becomes less powerful when the applicant presents his/her residence first.

This assumption challenges the "cumulative perception" of stigmas according to which one disad-

\footnotetext{
${ }^{13}$ We have observed, in this context and in other studies (Bonnet et al., 2011), that landlords are very cautious in their selection of tenants, probably because the French legal environment makes evictions a long and difficult process. We also noticed that some landlords discriminate against lawyers. Our analysis was that this was related to the complexity of the rules on eviction and the financial cost for landlords associated with the risk of default on the rent.

${ }^{14}$ According to the European Community Household Panel (1994-2002), 10.6\% of tenants self-reported in the survey that they had experienced a default on the rent in the last year. Some of these defaults were only temporary, but others were recurrent problems of default.
} 
vantaging factor would simply add a discriminatory effect to the other. Instead of this additive effect (residence would disadvantage everyone but even more ethnic minority candidates), our findings suggest that one variable (residence) may substitute the other (ethnicity) making its effect redundant especially when it is the first of the two pieces of information revealed in a potentially discriminatory interaction. It is also important to note that this redundancy appears to take place through a proxying process. Some elements in the interviews support the fact that residence may be used to proxy ethnicity. Indeed, the very few interviewees who elaborated on the question about residential discrimination mentioned "cultural arguments" directly linked to ethnic origin: fluency and accent in French.

Overall, H3 helps understand the results related to the geographic origin effect in the regressions performed with the phone conversations from procedure 2: because ethnic origin has been revealed at the beginning of the conversation, the proxying process of ethnicity through residence is not activated. However, this still does not solve the puzzle of the lack of significance of the ethnic origin variable in the procedure where ethnicity was revealed first to the real estate agent, and residence was revealed later. Possible explanations may draw on the weakness of names in proxying ethnicity in France. ${ }^{15}$ Residential origin may hence be a more effective proxy of ethnicity. Using in-person testers can be a useful strategy to eliminate this possible proxying process and better disentangle between the effects of ethnic and residential origins while measuring discrimination.

\section{Conclusion}

Our approach necessarily implies some limitations. First, housing search involves several steps. Our audit study analyzes only the earliest stage of this process. Whilst this would be problematic to measure the overall level of discrimination, we think that it is relevant for our less ambitious puspose, which is detecting the existence of discriminatory practices. These are readily visible in the first contact between housing applicants and real-estate agents.

This being acknowledged, the paper adds to the urban literature on residential segregation by providing empirical support for the argument that living in a given neighborhood may hinder households' residential mobility. We contribute to the scholarship on place-based exclusion, already documented on redlining (Aalbers, 2007) and steering (Galster and Godfrey, 2005), by adding the rental market dimension. From a methodological perspective, our research shows the discrepancy between the results obtained using different methods (audit and face-to-face interviews). This may be due to the unconsciousness of some discriminating acts, that face-to-face interview should address in one way or another. This may also challenge the relevance of measuring interaction between discriminatory factors. The underlying framework of such studies is dominated by the cumulative or additive disadvantage paradigm.

\footnotetext{
${ }^{15}$ Names have been frequently used in paired-testing audit in France to signal ethnic origin and have been proven to have significant discriminatory effects. However, some recent quantitative analyses suggest that experience of discrimination in France is also highly frequent among "visible minorities" (Beauchemin et al., 2010) and may thus indicate that testing studies should try to measure discrimination through personal interactions. Personal interactions nevertheless increase methodological vulnerability of testing studies due to the well-known problem of individual heterogeneity.
} 
However, when two stigmas are so interconnected in social representations, substitution mechanisms can take place when one stigma proxies another. Further research should therefore explore the implications of such proxying processes on the measurement of discrimination.

From a substantive point of view, our dual research protocol has enabled us to discard one of our three hypotheses: the idea of pure residential discrimination does not make sense. Two non-exclusive hypotheses remain: a statistical discrimination conjecture where real estate agents make inferences about insolvency through information about residence, and a pure ethnic discrimination conjecture where residence is a proxy for race/ethnicity. Further research integrating qualitative insights and systematic data may help us resolve this.

\section{References}

Aalbers, Manuel B. 2007. "What types of neighbourhoods are redlined?" Journal of Housing and the Built Environment, 22(2): 177-198.

Adida, Claire L, David D Laitin, and Marie-Anne Valfort. 2014. "Muslims in France: identifying a discriminatory equilibrium.” Journal of Population Economics, (forthcoming).

Ahmed, Ali M, and Mats Hammarstedt. 2008. "Discrimination in the rental housing market: A field experiment on the Internet." Journal of Urban Economics, 64(2): 362-372.

Barou, Jacques. 2002. L’habitat des immigrés et de leurs familles. Paris: La documentation française.

Beauchemin, Cris, Christelle Hamel, Maud Lesné, Patrick Simon, and Equipe TEO. 2010. "Les discriminations: une question de minorités visibles." Population et sociétés, 466: 1-4.

Becker, Gary S. 1971. The Economics of discrimination. University of Chicago Press.

Bereni, Laure, and Alexandre Jaunait. 2009. “Usages de la diversité.” Raisons politiques, 35: 5-9.

Blank, Rebecca M, Marilyn Dabady, and Constance F Citro. 2004. Measuring racial discrimination. Washington D.C: National Academies Press.

Bonilla-Silva, Eduardo. 2013. Racism without racists: Color-blind racism and the persistence of racial inequality in America. Lanham, MD: Rowman \& Littlefield Publishers.

Bonnet, François, Etienne Lalé, Mirna Safi, and Etienne Wasmer. 2011. “À la recherche du locataire «idéal»: du droit aux pratiques en région parisienne." Regards croisés sur l'économie, 9: 216-227.

Bosch, Mariano, M Carnero, and Lidia Farre. 2010. "Information and discrimination in the rental housing market: Evidence from a field experiment." Regional Science and Urban Economics, 40(1): 11-19. 
Breem, Yves. 2009. “Les conditions de logement des immigrés en 2006.” Infos migrations, Vol. 7.

Brueckner, Jan K, and Yves Zenou. 2003. "Space and unemployment: The labor-market effects of spatial mismatch.” Journal of Labor Economics, 21(1): 242-262.

Cediey, Eric, and Fabrice Foroni. 2008. Discrimination in access to employment on grounds of foreign origin in France: A national survey of discrimination based on the testing methodology of the International Labour Office. ILO.

Charles, Camille Zubrinksy. 2009. Won't you be my neighbor: Race, class, and residence in Los Angeles. New York: Russell Sage Foundation.

Charrier, Rémi, Jean-Jacques Guillouet, Philippe Pauquet, and Mathilde Turpin. 2008. "Les conditions de logement en Île-de-France en 2006." Île de France: à la page, 298.

Committee on National Statistics. 2002. Measuring housing discrimination in a national study: report of a workshop. Washington D.C: National Academies Press.

Committee on National Statistics. 2004. Measuring housing discrimination. Washington D.C: National Academies Press.

Coz, Gaëlle, and Genevieve Prandi. 2012. "Le parc locatif privé de l'agglomération parisienne au 1er janvier 2011." Se loger: Repères - Collection de l observatoire des loyers.

Crane, Jonathan. 1991. "The Epidemic Theory of Ghettos and Neighborhood Effects on Dropping Out and Teenage Childbearing." The American Journal of Sociology, 96(5): 1226-1259.

Decondé, Claire. 2012. "Première baisse significative de la vacance en Île-de-France depuis plusieurs décennies." Île de France: à la page, 381.

Denton, Nancy A, and Douglas Massey. 1993. American apartheid: Segregation and the making of the underclass. Harvard University Press.

Doytcheva, Milena. 2010. "Usages français de la notion de diversité: permanence et actualité d'un débat." Sociologie, 1(4): 423-438.

Duguet, Emmanuel, Yannick L'Horty, and Florent Sari. 2009. "Sortir du chômage en Île-de-France." Revue économique, 60(4): 979-1010.

Duguet, Emmanuel, Yannick L'Horty, and Pascale Petit. 2011. "Residential Discrimination and Ethnic Origin: An experimental assessment in the Paris suburbs." TEPP, Unpublished Manuscript.

Duguet, Emmanuel, Yannick L'Horty, Loïc Du Parquet, Pascale Petit, and Florent Sari. 2010. “Les effets du lieu de résidence sur l'accès à l'emploi: une expérience contrôlée sur des jeunes qualifiés 
en Île-de-France." Rapport pour l'Agence nationale pour la Cohésion Sociale et l'Egalité des chances (ACSé).

Ewens, Michael, Bryan Tomlin, and Liang Choon Wang. 2014. "Statistical discrimination or prejudice? A large sample field experiment." Review of Economics and Statistics, 96(1): 119-134.

Fernandez, Roberto M, and Celina Su. 2004. "Space in the study of labor markets." Annual Review Sociology, 30: 545-569.

Fiske, Susan T. 2000. "Stereotyping, prejudice, and discrimination at the seam between the centuries: Evolution, culture, mind, and brain.” European Journal of Social Psychology, 30(3): 299-322.

Fix, Michael, and Raymond Struyk. 1993. "Clear and convincing evidence: Measurement of discrimination in America." Washington, DC: Urban Institute Press.

Galster, George, and Erin Godfrey. 2005. "By words and deeds: Racial steering by real estate agents in the US in 2000.” Journal of the American Planning Association, 71(3): 251-268.

Gobillon, Laurent, Peter Rupert, and Etienne Wasmer. 2014. "Ethnic unemployment rates and frictional markets." Journal of Urban Economics, 79: 108-120.

Gobillon, Laurent, Thierry Magnac, and Harris Selod. 2011. "The effect of location on finding a job in the Paris region.” Journal of Applied Econometrics, 26(7): 1079-1112.

HALDE. 2006. "La discrimination dans l'accès au logement locatif privé." Haute Autorité de Lutte contre les Discriminations et pour l'égalité, ASDO études.

Heckman, James J. 1998. “Detecting Discrimination.” Journal of Economic Perspectives, 12(2): 101116.

Hunter, Rosemary. 1992. Indirect discrimination in the workplace. Federation Press.

INSEE. 2012. “Immigrés et descendants d'immigrés en France.” Insee Références - Édition 2012.

Jankel, Stéphanie, and Laurianne Salembier. 2008. “1996-2006: 10 ans de logement à Paris et en petite couronne." Île de France: à la page, 301.

Johnston, Ron, Michael Poulsen, and James Forrest. 2007. "The geography of ethnic residential segregation: a comparative study of five countries." Annals of the Association of American Geographers, 97(4): 713-738.

Kirschenman, Joleen, and Kathryn M Neckerman. 1991. "We'd love to hire them, but...: The meaning of race for employers." The urban underclass, (edited by C. Jencks and P. Peterson): 203-232.

LaPiere, Richard T. 1934. “Attitudes vs. actions.” Social forces, 13(2): 230-237. 
Meurs, Dominique, Ariane Pailhé, and Patrick Simon. 2006. "The persistence of intergenerational inequalities linked to immigration: Labour market outcomes for immigrants and their descendants in France.” Population (english edition), 61(5): 645-682.

Musterd, Sako. 2005. "Social and ethnic segregation in Europe: levels, causes, and effects." Journal of urban affairs, 27(3): 331-348.

Pager, Devah. 2007. "The use of field experiments for studies of employment discrimination: Contributions, critiques, and directions for the future." Annals of the American Academy of Political and Social Science, 609(1): 104-133.

Pager, Devah, and Hana Shepherd. 2008. "The sociology of discrimination: Racial discrimination in employment, housing, credit, and consumer markets.” Annual review of sociology, 34: 181.

Pager, Devah, and Lincoln Quillian. 2005. "Walking the talk? What employers say versus what they do." American Sociological Review, 70(3): 355-380.

Peach, Ceri, Vaughan Robinson, and Susan Smith. 1981. Ethnic segregation in cities. London: Croom Helm.

Phelps, Edmund S. 1972. "The statistical theory of racism and sexism." The American Economic Review, 62(4): 659-661.

Préteceille, Edmond. 2009. "La ségrégation ethno-raciale a-t-elle augmenté dans la métropole parisienne?" Revue française de sociologie, 50(3): 489-519.

Rathelot, Roland, and Mirna Safi. 2014. 'Local ethnic composition and natives' and immigrants' geographic mobility in France, 1982-1999.” American Sociological Review, 79(1): 43-64.

Ross, Stephen L, and John Yinger. 2002. The color of credit: Mortgage discrimination, research methodology, and fair-lending enforcement. Cambridge, Mass.: The MIT Press.

Sabbagh, Daniel, and Shanny Peer. 2008. "French color blindness in perspective: The Controversy over "Statistiques Ethniques"." French Politics, Culture \& Society, 26: 1-6.

Safi, Mirna. 2008. “The immigrant integration process in France: Inequalities and segmentation.” Revue française de sociologie (English Issue), 49(5): 3-44.

Safi, Mirna. 2009. "La dimension spatiale de l'intégration: évolution de la ségrégation des populations immigrées en France entre 1968 et 1999." Revue française de sociologie, 50(3): 521-552.

Safi, Mirna. 2013. Les inégalités ethno-raciales. Repères - Paris: La Découverte.

Safi, Mirna, and Patrick Simon. 2014. "La mesure des discriminations ethniques et raciales: représentations, expériences subjectives et situations vécues." Économie et Statistique, (forthcoming). 
Sampson, Robert J, and Patrick Sharkey. 2008. "Neighborhood selection and the social reproduction of concentrated racial inequality." Demography, 45(1): 1-29.

Sampson, Robert J, Jeffrey D Morenoff, and Thomas Gannon-Rowley. 2002. "Assessing "neighborhood effects": Social processes and new directions in research." Annual review of sociology, 28: 443478.

Samuelson, Paul A. 1938. "A note on the pure theory of consumer's behaviour." Economica, 51(17): 6171.

Schuman, Howard, Charlotte G Steeh, Lawrence Bobo, and Maria Krysan. 1997. Racial attitudes in America: Trends and interpretations. Cambridge: Harvard University Press.

Silberman, Roxane, Richard Alba, and Irène Fournier. 2007. "Segmented assimilation in France? Discrimination in the labour market against the second generation." Ethnic and Racial studies, 30(1): $1-27$.

Simon, Patrick. 2008. "The choice of ignorance: The Debate on ethnic and racial statistics in France." French Politics, Culture \& Society, 26(1): 7-31.

Turner, Margery Austin. 1992. "Discrimination in urban housing markets: Lessons from fair housing audits." Housing Policy Debate, 3(2): 183-215.

Turner, Margery Austin, Rob Santos, Diane K Levy, Doug Wissoker, Claudia Aranda, and Rob Pitingolo. 2013. "Housing Discrimination against Racial and Ethnic Minorities 2012: Full Report."

Verdugo, Gregory. 2011. "Public housing and residential segregation of immigrants in France, 19681999." Population (English Edition), 66(1): 169-194.

Wacquant, Loïc. 2008. Urban outcasts: A comparative sociology of advanced marginality. Cambridge: Polity.

Waddington, David, Fabien Jobard, and Mike King. 2013. Rioting in the U.K. and France: A comparative analysis. Portland, OR: Willan.

Wasmer, Etienne, and Yves Zenou. 2002. “Does city structure affect job search and welfare?" Journal of Urban Economics, 51(3): 515-541.

Wilson, William Julius. 1978. The declining significance of race: Blacks and changing American institutions. University of Chicago Press.

Wilson, William Julius. 1987. The truly disadvantaged: The inner city, the underclass, and public policy. University of Chicago Press. 
Yinger, John. 1986. "Measuring Racial Discrimination with Fair Housing Audits: Caught in the Act." The American Economic Review, 76(5): 881-893.

Yinger, John. 1998. "Housing discrimination is still worth worrying about." Housing Policy Debate, 9(4): 893-927. 


\section{A Audit study design}

This appendix provides an extensive description of our audit study.

\section{A.1 Background and prior methods}

Our audit study was largely inspired by prior audits that have been conducted elsewhere than in France. The example of the United States is by far the most influential. Since the late 1970s, the U.S. Department of Housing and Urban Development (HUD) has been monitoring series of nationwide paired-testing audit studies in both rental and sales markets. The objectives, methods and results of these studies are carefully documented in reports published by the HUD's office of development and research. They define the state of the art in the implementation of audit methods and provide thorough discussions of the statistical procedures used to analyze audit data. ${ }^{16}$ This section provides a brief description of these canonical audit studies to help the reader understand better how our own audit study was designed and implemented.

Nationwide audit studies monitored by the HUD have been conducted once every decade since the first study launched in 1977. Over time, the scope and methods have evolved, but there is unity in several features that can be summarized as follows:

1. Experiment: In its very essence, a housing audit study is an experiment where two testers (one from the majority group and the other from a minority group) are matched, trained to appear comparable in several observable dimensions and then put into contact with real estate and rental agents (Turner, 1992).

2. Measurement: The outcome (or treatment) received by each tester can be encoded and subsequently used in statistical analysis. Systematic comparison of these outcomes allows detecting discrimination against one tester of the pair. Ultimately, differential treatments can be summarized by statistics. It should be underlined that what is being measured is often subject to debates (Heckman, 1998; Yinger, 1998), and also that interpretability is not the unique purpose of these statistics. Indeed, the HUD aims at producing figures that can be compared across regions and over time; interpretation set aside, those allow measurement of geographic differentials and/or time trends.

3. Selection of testing areas: Cost and logistic considerations suggest that metropolitan areas are best designated for conducting audit studies. Since the HUD aims at producing representative estimates, it uses Census data to draw samples of metropolitan testing sites and to achieve high coverage of areas with minorities. The 2012 national audit study for instance covers 28 metropolitan sites (Turner et al., 2013).

\footnotetext{
${ }^{16}$ Of course, these paired-testing audit studies are not the only housing audit studies in the United States. Many smaller scale housing audits also exist and have been conducted since the first national audit study of 1977; see for instance Yinger (1986) for an analysis of an early local audit study conducted in Boston in 1981.
} 
4. Selection of advertisements: Advertisements are drawn in accordance with routine search behaviors of housing applicants. Historically, audit studies have relied on advertisements found in major newspapers (Turner, 1992; Yinger, 1998). The 2012 audit study adapted its protocol to reflect new practices brought about by technology changes over the past decades; it sought to take into account housing searches via cell phone, the Internet, etc. (Turner et al., 2013).

5. Selection of the minority group: The minority group is chosen in order to test for potential discriminatory actions against that specific group. For instance the 1977 audit study tested for discrimination against Black housing applicants only. The 1989 audit study extended the experiment to Hispanic housing applicants and the 2000 audit study to Hispanic, Asian and Native American housing applicants (Turner, 1992; Turner et al., 2013).

The nationwide audit studies just described are tailored to address specific concerns in relation to race or ethnicity in the U.S., and to assess enforcement of the federal law (the 1968 Fair Housing Act). Our paired-testing audit study contrasts in scope and objective and we can summarize the major differences as follows:

- We focus on a single metropolitan area. Our goal is not produce nationally-representative figures on housing discrimination. Instead, we test whether minority home-seekers systematically receive less favorable treatments within a geographic area where market tightness induces landlords to be very selective about applicants.

- We focus on the first possible contact between applicants and rental agents, i.e. phone conversations, and we do not organize face-to-face meetings. This choice was not dictated by budget limitations only; as explained below, phone conversations are well designated to capture potential discriminatory actions that we seek to study.

- We focus on the private rental housing market. Buying a home is a relatively more complex process and it is clear that phone conversations would be less effective in detecting potential discriminatory actions involved in this process. Moreover, the scenario of our audit study would have been less plausible in the context of home buying, particularly for apartments located within the city of Paris.

Our paired-testing audit nevertheless retains some of the unifying characteristics listed above. Broadly speaking, our study reproduces the experiment described in (1) and (2): we matched an individual from a majority (white) group with an individual from a minority group, put them into contact with real estate agents and compared the treatment each of them received. How the unifying traits (3) and (4) reflected in our audit study is explained in Sections A.2 and A.3 below: those provide detailed information about the targeted metropolitan area and ads that we sampled. The remaining unifying trait (5) is discussed in Sections A.4 and A.5 which describe the selection of testers and their fictitious identities. 


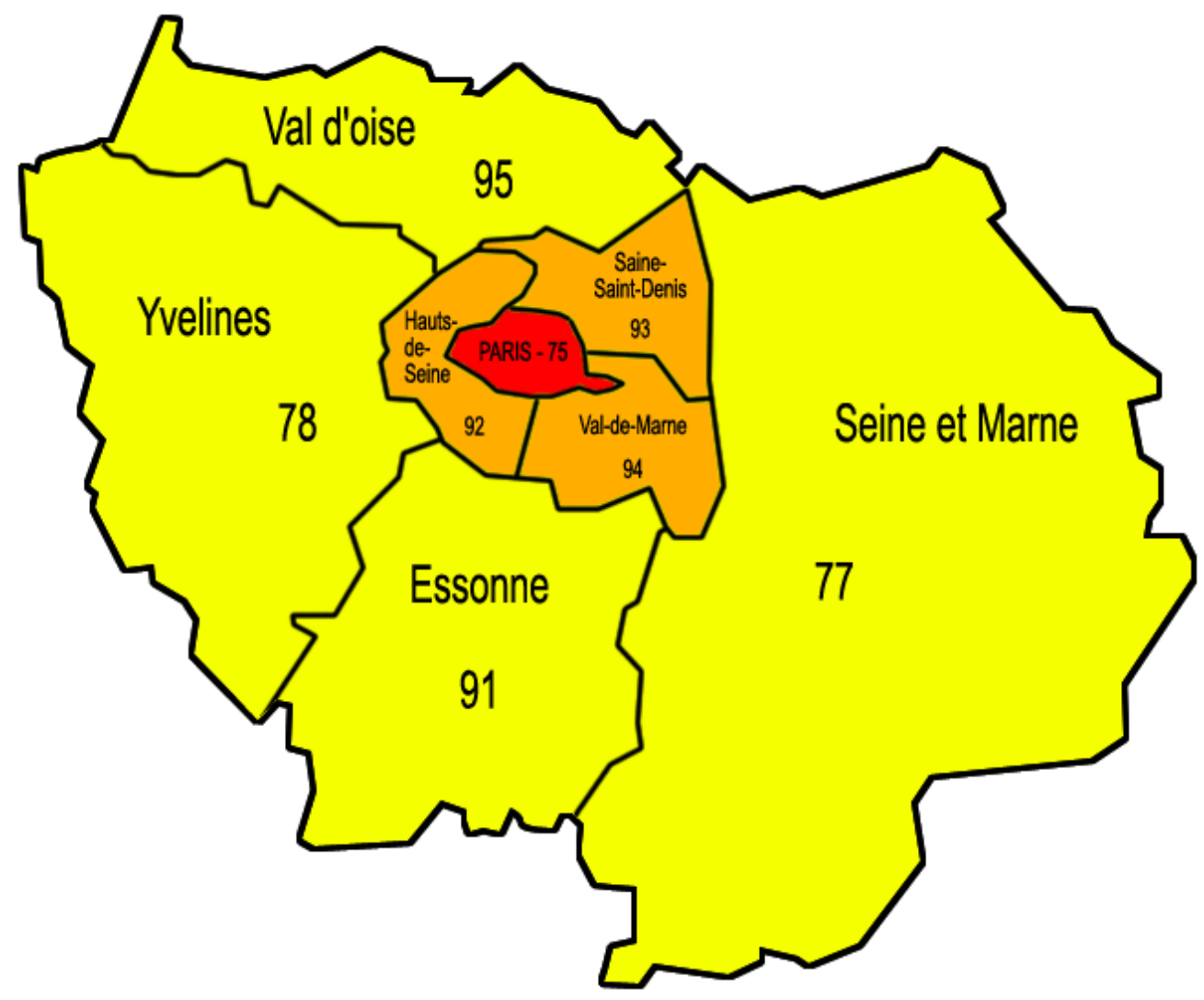

Figure A1. Map of région Île-de-France

\section{A.2 Targeted metropolitan area}

Our audit study was done in Paris and in several cities of the region Île-de-France. We focused on the private rental housing market, which accounts for 35\% of the housing stock in Paris, and for $21 \%$ of the housing stock in the whole region Île-de-France (figures for the year 2006 excerpted from Jankel and Salembier, 2008). ${ }^{17}$

Within the city of Paris, we sampled Internet postings on the popular website http://www . seloger . com for housing units located in almost all arrondissements (administrative district) of Paris and obtained observations for 14 out of the 20 arrondissements. Outside the city of Paris, we restricted the study to cities with direct connections by public transportation (metro or RER) to Paris. The data resulting from our audit study thus include housing units located inside Paris, in some cities from the "inner ring" (départements 92, 93 and 94) and in some cities from the "outer ring" (départements 77, 78, 91 and 95) - see Figure A1.

Table A1 displays a set of statistics characterizing the housing vacancies of our audit study. We also report descriptive statistics about the size and rent of privately rented apartments in the Paris region. We targeted apartments for couples without kids. As shown in the table, the surface areas in our dataset fall well in the range of one- to two-room apartments as measured by representative surveys. Rents per square

\footnotetext{
${ }^{17}$ Within the European Union, France has a slightly lower home ownership rate compared to the European average : 58\% against 65 in the EU in 2007 ; the rate increased in France since then and is about 62\% in 2013.
} 
Table A1. Characteristics of the housing units, in our audit study and overall

\begin{tabular}{|c|c|c|c|c|c|c|c|}
\hline & \multicolumn{4}{|c|}{ Sample of our audit study } & \multicolumn{3}{|c|}{ Representative sample } \\
\hline & $N$ & $\begin{array}{l}\text { Rent } \\
(€)\end{array}$ & $\begin{array}{c}\text { Surface } \\
\text { (Sq. meter) }\end{array}$ & $\begin{array}{c}\text { Rent per Sq. } \\
\text { meter }(€)\end{array}$ & $\begin{array}{c}\text { Surface } \\
\text { one-room } \\
\text { (Sq. meter) }\end{array}$ & $\begin{array}{c}\text { Surface } \\
\text { two-room } \\
\text { (Sq. meter) }\end{array}$ & $\begin{array}{c}\text { Rent per Sq. } \\
\text { meter }(€)\end{array}$ \\
\hline Full sample & 250 & 749 & 41 & 19.30 & & & 22.46 \\
\hline Median & & 748 & 39 & 18.60 & & & \\
\hline $25 \%$ centile & & 685 & 33 & 16.18 & & & \\
\hline $75 \%$ centile & & 815 & 46 & 21.52 & & & \\
\hline Median in Paris & 45 & 750 & 32 & 25.00 & 25 & 42 & 28.06 \\
\hline Median in Dept. 77 & 37 & 660 & 40 & 16.67 & 27 & 44 & 14.00 \\
\hline Median in Dept. 78 & 37 & 815 & 45 & 18.17 & 29 & 48 & 17.44 \\
\hline Median in Dept. 91 & 40 & 706 & 42 & 17.32 & 30 & 42 & 15.04 \\
\hline Median in Dept. 92 & 38 & 716 & 33 & 21.18 & 27 & 44 & 22.92 \\
\hline Median in Dept. 93 & 2 & 720 & 35 & 20.61 & 28 & 42 & 17.92 \\
\hline Median in Dept. 94 & 11 & 750 & 40 & 20.29 & 28 & 44 & 19.27 \\
\hline Median in Dept. 95 & 40 & 800 & 50 & 15.54 & 28 & 46 & 16.09 \\
\hline
\end{tabular}

NOTE: Surfaces are measured in square meters (Sq. meter); Rents are reported in euros (€). Representative figures for the surface area of one-room and two-room apartments are for the year 2011; they are extracted from an extensive report of the Observatoire des loyers (Observatory of rents) written by Coz and Prandi (2012). Representative figures for Rents per square meters are from the information-aggregator website http://www. lacoteimmo.com which gathers information on rents for apartments advertised online.

meter are also remarkably in line with the data; in particular, housing vacancies in our dataset reproduce the observed disparities across départements. Overall, the table suggests that housing vacancies that form the basis of our empirical work adequately match the housing stock of the Paris region.

Our focus on small-sized apartments advertised on the Internet was motivated by some further considerations. First, these are the apartments typically looked for by middle-class households such as our fictitious applicants. Second, the information provided on Internet postings is typically comprehensive. In the phone conversations, testers could thus limit their questions to availability and viewing. This has two advantages: to reduce the array of possible conversation outcomes and to minimize risks of suspicious real estate agents. The conclusion from our protocol is that this experimental design was sufficient to capture possible discriminatory actions at this early stage of the housing search process.

Vacancy rates for apartments are much higher in the region Île-de-France relative to the rest of France. No less than $70 \%$ of vacant housing units are located within the Paris metropolitan area (Decondé, 2012). $6.2 \%$ of all housing units located in the region Île-de-France are vacant, and the corresponding figures for the city of Paris alone rises to $9.2 \%$. This tightness of the housing market is not caused by a lack of housing applicants (Bonnet et al., 2011). Instead, it reflects the fact that landlords are very cautious in their selection of tenants, probably because the French legal environment makes evictions a long and difficult process. Higher vacancy rates in the region Île-de-France (and the possibility that it results in 
discriminatory actions) thus make it a relevant case for our audit study .

\section{A.3 Sampling of ads}

We collected advertisements for housing units from the website http://www. seloger.com. This is a major platform for real estate agents who choose to advertise their vacancies on the Internet. Users can sort advertised units along a number of criteria, such as the rent, size, location, etc. Our focus on relatively small-sized apartments, located in specific geographical area and for a selected rent range implies that we could almost exhaust the corresponding units advertised on the website. As shown in Table A1, the latter provided a close-to-representative cross-section of the targeted housing units located in the Paris metropolitan area. Further, it covers a large share of online connections to real estate agencies' advertisements. According to the French audience measurement company Mediamétrie, Se loger was the first online agency in France in 2009-2010 (time of the survey) and was still second in 2012. It had more than 3 millions of monthly single IP connections, amounting to $7 \%$ of all internet users in France. ${ }^{18}$

\section{A.4 The testers}

Our audit study was carried out by a team of 8 individuals, aged 22 to 28,2 women and 6 men (hereafter: the "testers"). All testers were highly skilled and were fully informed about the situation, of what was to be tested, and knew that any deviation from the methodology would invalidate the results. Two half-day training sessions were also organized to give testers a better understanding of the objective. They were all explicitly told the following: "We don't know whether there is discrimination along those dimensions. Remain neutral, both during the phone call and in reporting the results." They were asked to report a maximum of qualitative information. In particular, there was a variable to indicate "a suspicion of audit", included to report questions by the agent such as "Did you call yesterday?". This occurred overall in 7 cases out of 340 calls during the first phase. All testers were explicitly involved in the design of part of the procedures, notably to determine the final encoding of variables.

Our testers did not have any particular accent, and we instructed them not to fake any during the phone conversations. Our main concern was that accents typically associated to French minority suburbs convey information about both residential and ethnic origins, which we aimed to disentangle in this study. Thus, we suspected that accents would, in general, reinforce the impact of any of our two discriminatory criteria while making the interpretation of the coefficients more difficult. Setting aside accents was also dictated by the fact that the relevant information about residential or ethnic origin was to be revealed at the very beginning of phone conversations, which turned out to be very brief. Accents would have added a complex ingredient to these short talks, and we found this undesirable: any effect of ethnicity would have been jointly attributed to ethnicity itself and to the lack of cultural integration this accent would have revealed.

\footnotetext{
${ }^{18} \mathrm{http}$ ://www. journaldunet.com/ebusiness/le-net/immobilier-mediametrie/seloger.shtml
} 


\section{A.5 Scenarii}

Testers were assigned fictitious identities designed to impersonate the average housing applicant in the Paris region. Fictitious identities would include a name, a place of residence, an occupation and an income level, for instance: "Sébastien Fournier (French name) / Kader Boualem (North African name), lives in La Courneuve (deprived suburb) / Versailles (rich suburb), is 31 years-old, works as an accountant and earns a monthly wage of 1,700€". These identities also included a marital status (married with no kid), an occupation and an income for the spouse: typically, "works as a secretary and earns 1,300€ per month". Finally, testers were attributed a geographical area around Paris that would be consistent with their asserted willingness to relocate.

Our choice of fictitious identities was motivated by the following observations:

- According to Charrier et al. (2008), the monthly income of household applying for housing on the Paris private rental housing market was $2,909 €$ in the census year $2006(2,638 €$ for the region Île-de-France as a whole), and average household income was $3,103 €$ in Paris $(3,131 €$ at the level of the region).

- The same study reports that professionals (Cadres et professions intellectuelles supérieures) account for one-third of the population working in Paris, and is even higher among those applying for housing on the rental market (as high as 52\%). This is followed by intermediary professions (Professions intermediaires, i.e. clerical workers with university education) which account for $14 \%$ of the population in the Paris metropolitan area. The occupations for the fictitious applicant and his/her partner were selected to reflect these figures.

With regards to asserted ethnic and residential origins, those were selected as follows:

- Names were chosen to signal origin from either France or North Africa. We followed the methodology of the International Labour Office described by Cediey and Foroni (2008). Specifically, we used the following "North-African" fictitious names: Rachid Ammelal, Mehdi Belbouab, Hafsa Belhadj, Farid Boukhrit, Kader Boualem, Habib El Bekkali and Fathia Laouadi; for "white French" ones: Marion Denis, Pascal Dubois, Sébastien Fournier, Sébastien Pialoux, Julie Morvan, Julien Roche and Gilles Rousseau.

- The fictitious current locations were chosen among cities of the Île-de-France region that are either notoriously deprived, or privileged. Some of the selected deprived cities had experienced the 2005 urban riots. Cities used to signal deprived neighbourhoods were: Bagneux, Bondy, Gennevilliers, Saint Ouen, Sarcelles, Trappes and Villeneuve Saint-Georges; cities used to signal privileged neighbourhoods were Le Raincy, Levallois, Meudon, Nogent sur Marne, Sceaux, Versailles and Vincennes.

We collected and reported in Table A2 some summary statistics about each of the city of respondents in our audit study. Further, what matters in the selection process is the typical representations of these neighbourhoods (good vs. bad) as, for instance, conveyed by the media after 
Table A2. Characteristics of cities selected in the audit

Share of owners Median income Unemp. Rate 15-64 Share of immigrants

$(\%)$

(*)

$(\%)$

$(\%)(* *)$

a. Cities used to signal deprived neighbourhoods

$\begin{array}{lllll}\text { Bagneux } & 25.7 & 17,508 & 14.2 & 21.2 \\ \text { Bondy } & 43.8 & 14,088 & 18.8 & 28.8 \\ \text { Gennevilliers } & 19.6 & 13,614 & 18.5 & 30.6 \\ \text { Saint Ouen } & 20.5 & 14,505 & 18.7 & 32.4 \\ \text { Sarcelles } & 33.7 & 12,189 & 23.2 & 31.3 \\ \text { Trappes } & 26.1 & 13,563 & 17.4 & 26.1 \\ \text { Villeneuve Saint-Georges } & 37.7 & 13,862 & 16.7 & 28.5\end{array}$

b. Cities used to signal privileged neighbourhoods

$\begin{array}{lcccc}\text { Le Raincy } & 61.9 & 27,430 & 9.7 & 11.0 \\ \text { Levallois-Perret } & 37.1 & 30,761 & 9.5 & 14.7 \\ \text { Meudon } & 54.2 & 28,359 & 8.5 & 13.5 \\ \text { Nogent sur Marne } & 52.7 & 30,680 & 9.8 & 13.0 \\ \text { Sceaux } & 46.4 & 35,558 & 8.8 & 10.6 \\ \text { Versailles } & 45.8 & 30,577 & 7.9 & 8.8 \\ \text { Vincennes } & 48.1 & 31,408 & 8.7 & 13.2\end{array}$

NotE: All variables are for the year 2011, except the share of immigrants (2012). (*) In euro ( $€$ ) per consumption unit. $(* *)$ French definition of immigrants: persons born abroad and not French at birth (Haut Conseil de l'Intégration).

the 2005 urban riots. The true statistics are (sadly) less relevant in decision making than perceptions. As an anecdote, a recent IPSOS poll indicate that in France, respondents overestimate by almost a factor 4 the share in population of Muslims in France (estimated to be 31\% against an actual population of $8 \%$ according to http://www. economist.com/blogs/graphicdetail/ 2015/01/daily-chart-2). A professional real estate agent from the Paris region could not ignore the social connotations of the chosen cities.

Although our team included two women, we made no attempt to test for discrimination by gender. Indeed, given the limited number of calls that could be made, it appeared desirable to limit the number of potentially discriminatory combinations and to focus on ethnic and residential stigma. The two female testers of our team would thus always work in tandem. Overall, we noticed no significant differences between the outcomes reported by our pair of female testers relative to male testers.

\section{A.6 Location and Technical Details}

Testers were installed in an office provided by our university (Sciences Po). They called from two separate phones. The first one was installed on a fixed line, opened for this testing procedure as for a private household and the number of which started in 01 (Paris and suburbs region). Importantly, it differed from 
the Sciences Po numbers that all start with the six numbers 0145 49. The second one was installed on an Internet box provided by the telephone company, the number starting in 09 which is not specific to any region. Both phones had an answering machine. In addition, the first tester was given a cell phone. When rental brokers asked for a phone number to call back, the first tester would give the cell phone number and the second tester would give the number starting in 09 (which does not necessary indicates a fixed line). Testers would never call at the exact same time; they would instead work sequentially. Phone calls were given during regular office hours on weekdays. Providing testers with an answering machine appeared necessary in order to refine the measurement of the outcome of the conversations.

\section{A.7 Timing}

A typical session consisted in a sequence of phone calls (i) to vacancies that had been contacted before and (ii) to new vacancies. The first tester reported the day and hour of the phone call as well as an identifier of the vacancy so that the second tester could call back the same vacancy after a "long enough" period of time had elapsed. As the duration between the two calls increased, the outcome of the second call was more likely to be negative for reasons unrelated to discrimination: for instance, another applicant might have called after the first tester. It was thus necessary to limit the time between calls as much as possible. However, the audit was more likely to be suspected if the interval was too short, so testers were encouraged not to wait too long to make the second call. We found a period of half a day to one day to be a good compromise between these constraints, and testers were able to follow this procedure in most cases.

We insisted on switching the order in which phone calls were made, so that the tester responsible with the role of minority applicant would call first as often as the other tester. Every four calls, testers thus had to invert the order. In the resulting dataset, the order is perfectly balanced across pairs of calls and there is hence no systematic association with the fictitious identities of the testers.

\section{A.8 Encoding}

As indicated in the body of the paper, the outcomes of conversations were coded as follows:

\begin{tabular}{cl} 
Code & Outcome \\
\hline 1 & Apartment is already rented, nothing else available \\
2 & Caller is asked to send a written application with personal details \\
3 & Real estate agent will call back, but no return call \\
4 & Apartment is already rented but something else is available \\
5 & Real estate agent plans a group visit \\
6 & Real estate agent plans an individual visit
\end{tabular}

The outcomes are rank-ordered. We decided on this method of coding after several days of trials and about 50 calls. Code 4 was considered inferior to 5 and 6 because it may indicate steering. Code 
3 could have been considered inferior to Code 2, but the testers themselves reported that Code 2 was frequently a polite way to send applicants off. Code 3 on the other hand might be due to a random event, especially during rush hours and because of the high turnover rates for Paris apartments. Finally, Code 3 was changed appropriately into 4, 5 or 6 when real estate agents called back as promised or left a message on the answering machine of each tester.

When testers were redirected towards a different apartment (Code 4), we were unable to test whether this could be due to steering because testers were usually not given sufficiently many details about the alternative offer. We note that this was located in the same city in most cases and there are hence reasons to assume that the other unit was a proper substitute. However, because we cannot test this assumption directly, we offer robustness checks in Appendix B with respect to Code 4.

\section{A.9 Additional information}

We conducted about 50 experimental phone calls before opting for our final setup. Two constraints appeared worthy of consideration. First, although there were, in principle, four scenarios that we would have liked to test (good name/good location, bad name/good location, etc.), we could not ask four testers to contact the same advertised dwelling. To avoid detection of the audit, it was necessary to impose a delay of at least 24 hours between phone calls for the same vacancy. With four scenarios, this would have required almost a week to contact the same vacancy, which, given the high rate of turnover of the housing vacancies contacted, was not feasible. Second, the typical phone conversation was extremely short (often less than one minute), which limited the number of "signals" (geographic origin or ethnic origin) that could be revealed within the phone conversation.

Throughout the duration of the experiment, we had frequent debriefings with our team. We asked tester to report subjective information about each phone calls in order to monitor them more efficiently. Eventually, we were able to check whether this information (which we encoded in our final dataset) affected the variability of the outcome across testers and/or across phone conversations and found no systematic relationship.

\section{A.10 External validity and replication}

Due to budget limitations, we were not able to extend our audit study to other major metropolitan areas of France, such as Lyon or Marseille. The Paris region is much bigger, more diverse, and overall more economically developed than provincial urban agglomerations. It is hence a natural candidate to conduct experiments aimed at assessing the extent and nature of discrimination in France. Further research in the rest of France would also be informative especially to uncover regional patterns, and would provide valuable material for comparisons.

We noted above that our experimental design appeared sufficient to capture possible discriminatory actions at the early stage of the housing search process. We hope to have provided enough details in this 
appendix to allow for replication of the study. Our design could also be adapted to specific settings in other countries. Finally, the detailed depiction of our experiment provided in this appendix should allow direct comparison to the methods implemented in other audits. 


\section{B Additional tables and results}

\section{Cross-tabulation of the outcomes}

As shown in Figure 1 in the paper, outcome 6 (individual visit planned) and 3 (we will call you back but no return call) were the most frequent outcomes of the phone conversations. In Tables B1 and B2, we crosstabulate the outcomes. This is instructive because if we were to analyze only the phone conversations which resulted in these two outcomes only, the detection of discriminatory practices would come from rows and columns 3 and 6 in the Tables. Fortunately for the purpose of identification, we notice that when one candidate was told that he/she would be called back, the other candidate was told the same thing in only half of all cases. Furthermore, the table indicates that this tended to be more favorable to the majority candidate in the first procedure. Indeed, when the majority candidate was to be called back, the minority candidate obtained an individual viewing in $23 \%$ of all cases (row 3, column 6 in Table B1), whereas when the minority candidate was told to expect a phone call back, the majority candidate managed to arrange an individual visit in $39 \%$ of all cases (row 6, column 3 in Table B1). In the second procedure on the other hand, the odds were more balanced: these percentages become 27\% (row 3, column 6 in Table B2) and 17\% (row 6, column 3 in Table B2), respectively. This reiterates the finding that discriminatory practices affected the outcomes under the first procedure, but not in the second procedure.

\section{Robustness check 1: bootstrapping pairs in procedure \#1}

To assess the sensitivity of our results to the difference in sample sizes across procedures, we replicate the finding of procedure \#1 by boostraping pairs of phone calls so as to obtain comparable sample sizes. That is, we randomly select pairs of calls among the 177 initial pairs and re-estimate the generic linear models specified in the paper. We focus on our preferred specifications, i.e. regressions with auditlevel fixed effects (columns (IV)-(VII) in Table 3 of the paper). To accord with the sample sizes of the second procedure, we select 77 pairs. The results from the bootstrap procedure based on 500 replications are reported in Table B3. The significance level is reduced but the main coefficient of interest remains significant at the 10 percent level in regressions that control better for differences across individual phone calls (columns (III) and (IV)).

\section{Robustness check 2: sensitivity with respect to outcome no. 4}

As we note in Subsection A.8 of Appendix A, we were unable to test whether outcome 4 (Apartment is already rented but something else is available) could reflect steering instead of redirection towards a proper substitute for the initial apartment. Nevertheless, we can offer two series of robustness checks with respect to outcome no. 4 :

- First, we can group Code 4 with Codes 1, 2 and 3 ("rather negative outcome") and re-estimate our models. If our assumption that Code 4 indicated a neutral or either positive outcome, then we 


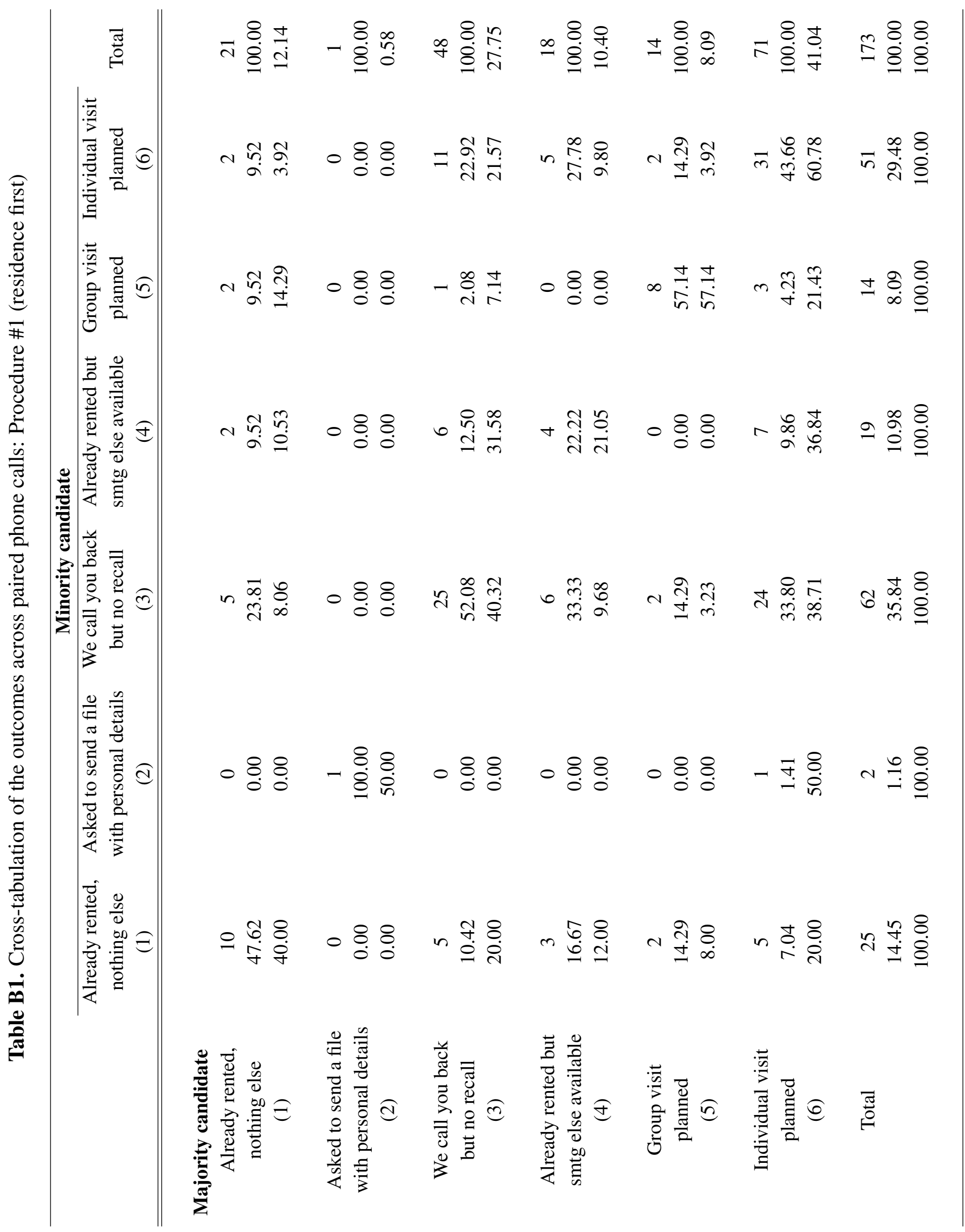




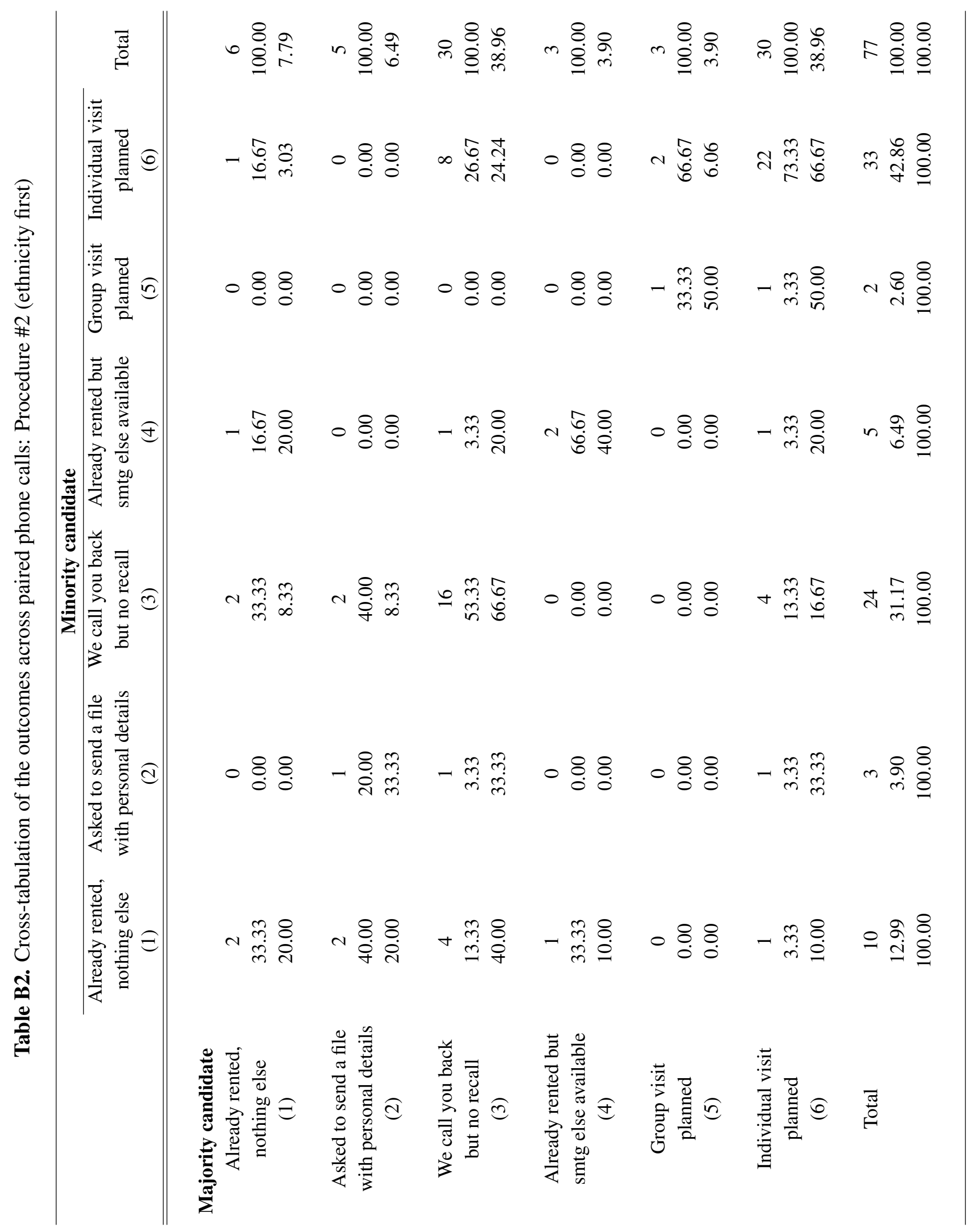


Table B3. Robustness check 1: discrimination rates with bootstraped pairs in procedure \#1

\begin{tabular}{lcccc}
\hline Procedure \#1 (residence first) & (I) & (II) & (III) & (IV) \\
\hline \hline & & & & \\
Deprived suburb & -0.1098 & -0.1227 & -0.1301 & -0.1373 \\
& $(0.0703)$ & $(0.0751)$ & $(0.0786)$ & $(0.0793)$ \\
Minority name (North Africa) & & & 0.1273 & 0.1046 \\
& & & $(0.1358)$ & $(0.1411)$ \\
Name revealed & & & 0.2415 & 0.2373 \\
& & & $(0.1465)$ & $(0.1494)$ \\
Name revealed x Minority Name & & & -0.1888 & -0.1747 \\
& & & $(0.1706)$ & $(0.1728)$ \\
\hline Controls: & & & & \\
$\quad$ Individual call & & $\mathrm{Y}$ & & $\mathrm{Y}$ \\
$\quad$ Audit fixed effects & $\mathrm{Y}$ & $\mathrm{Y}$ & $\mathrm{Y}$ & $\mathrm{Y}$ \\
\hline$N$ & 154 & 154 & 154 & 154 \\
$R^{2}$ & 0.0311 & 0.0443 & 0.0668 & 0.0775 \\
\hline
\end{tabular}

NotE: Standard errors in parentheses. Standard errors are obtained under a bootstrap procedure where 77 pairs are chosen randomly among the 177 initial pairs. Each column reports the coefficients $\gamma$ and $\beta$ estimated along with a specific set of controls. Name revealed is a dummy indicating whether the tester revealed his/her name in the phone conversation. Characteristics at the level of the individual phone calls are: a dummy indicating whether the tester used the phone line with a number starting with 09 (indicating Internet box) and a dummy indicating whether he/she called first.

expect the coefficient on the dummy for the minority candidate to be lower in absolute value. We also expect the fit of the regression to be lower than under the benchmark specification.

- Second, we can run our regressions on the subsample of audit pairs where neither the minority candidate nor the majority candidate was offered to visit a different housing unit. As this effectively reduces the size of the sample, we expect the coefficient to be less precisely, but without any change in sign.

For economy of space, here again we focus on our preferred specifications, i.e. with audit-level fixed effects. Table B4 reports the estimation results under the two audit procedures: columns (I)-(IV) show the results obtained after grouping Code 4 with Codes 1 to 3 and columns (V)-(VIII) show the results obtained after excluding outcome 4.

It is clear that our results are not driven by outcome no 4. Our estimates in the first procedure remain almost unchanged and statistically significant, even with a smaller sample size when audit pairs with Code 4 are excluded. Conversely, no significant change occurs in the second procedure. Overall, this robustness check confirms the analysis of Tables B1 and B2 showing that detection of discrimination (and the lack thereof) relies mostly on outcomes 3 and 6, but not on outcome 4 . 
Table B4. Robustness check 2: sensitivity with respect to outcome no. 4

\begin{tabular}{|c|c|c|c|c|c|c|c|c|}
\hline \multirow{2}{*}{$\begin{array}{l}\text { Procedure \#1 } \\
\text { (residence first) }\end{array}$} & \multicolumn{4}{|c|}{ Grouping Code 4 with Codes $1-3$} & \multicolumn{4}{|c|}{ Excluding Pairs with Code 4} \\
\hline & (I) & (II) & (III) & (IV) & $(\mathrm{V})$ & $(\mathrm{VI})$ & (VII) & (VIII) \\
\hline Deprived suburb & $\begin{array}{l}\mathbf{- 0 . 1 1 5 6} \\
(0.0449)\end{array}$ & $\begin{array}{l}\mathbf{- 0 . 1 2 2 7} \\
(0.0449)\end{array}$ & $\begin{array}{l}\mathbf{- 0 . 1 2 6 8} \\
(0.0503)\end{array}$ & $\begin{array}{r}\mathbf{- 0 . 1 2 8 4} \\
(0.0500)\end{array}$ & $\begin{array}{l}\mathbf{- 0 . 1 2 8 6} \\
(0.0496)\end{array}$ & $\begin{array}{l}\mathbf{- 0 . 1 3 2 4} \\
(0.0499)\end{array}$ & $\begin{array}{l}\mathbf{- 0 . 1 4 2 5} \\
(0.0545)\end{array}$ & $\begin{array}{l}\mathbf{- 0 . 1 4 5 3} \\
(0.0543)\end{array}$ \\
\hline $\begin{array}{l}\text { Minority name } \\
\text { (North Africa) }\end{array}$ & & & $\begin{array}{c}0.1046 \\
(0.0837)\end{array}$ & $\begin{array}{c}0.0873 \\
(0.0875)\end{array}$ & & & $\begin{array}{c}0.1679 \\
(0.0926)\end{array}$ & $\begin{array}{c}0.1639 \\
(0.0936)\end{array}$ \\
\hline Name revealed & & & $\begin{array}{c}0.1213 \\
(0.0957)\end{array}$ & $\begin{array}{c}0.1246 \\
(0.0964)\end{array}$ & & & $\begin{array}{c}0.1827 \\
(0.1048)\end{array}$ & $\begin{array}{c}0.1753 \\
(0.1063)\end{array}$ \\
\hline $\begin{array}{l}\text { Name revealed } \\
\text { x Minority Name }\end{array}$ & & & $\begin{array}{l}-0.1632 \\
(0.1099)\end{array}$ & $\begin{array}{l}-0.1584 \\
(0.1096)\end{array}$ & & & $\begin{array}{l}\mathbf{- 0 . 2 5 7 7} \\
(0.1200)\end{array}$ & $\begin{array}{l}\mathbf{- 0 . 2 4 8 3} \\
(0.1177)\end{array}$ \\
\hline \multicolumn{9}{|l|}{ Controls: } \\
\hline Individual call & & $\mathrm{Y}$ & & $\mathrm{Y}$ & & $\mathrm{Y}$ & & $\mathrm{Y}$ \\
\hline Audit fixed effects & $\mathrm{Y}$ & $\mathrm{Y}$ & $\mathrm{Y}$ & $\mathrm{Y}$ & $\mathrm{Y}$ & $\mathrm{Y}$ & $\mathrm{Y}$ & $\mathrm{Y}$ \\
\hline$N$ & 346 & 346 & 345 & 345 & 280 & 280 & 279 & 279 \\
\hline$R^{2}$ & 0.0373 & 0.0413 & 0.0543 & 0.0590 & 0.0463 & 0.0532 & 0.0823 & 0.0846 \\
\hline$R^{2}$ with fixed effect & 0.8010 & 0.8018 & 0.8077 & 0.8086 & 0.8272 & 0.8285 & 0.8369 & 0.8373 \\
\hline
\end{tabular}

\begin{tabular}{|c|c|c|c|c|c|c|c|c|}
\hline \multirow{2}{*}{$\begin{array}{l}\text { Procedure \#2 } \\
\text { (ethnicity first) }\end{array}$} & \multicolumn{4}{|c|}{ Grouping Code 4 with Codes $1-3$} & \multicolumn{4}{|c|}{ Excluding Pairs with Code 4} \\
\hline & (I) & (II) & (III) & (IV) & $(\mathrm{V})$ & $(\mathrm{VI})$ & (VII) & (VIII) \\
\hline \multirow[t]{2}{*}{ Minority name } & 0.0260 & 0.0323 & 0.0303 & 0.0367 & 0.0423 & 0.0526 & 0.0391 & 0.0478 \\
\hline & $(0.0524)$ & $(0.0585)$ & $(0.0572)$ & $(0.0674)$ & $(0.0549)$ & $(0.0599)$ & $(0.0597)$ & $(0.0694)$ \\
\hline \multirow[t]{2}{*}{ Deprived suburb } & & & 0.0375 & 0.0376 & & & 0.0285 & 0.0269 \\
\hline & & & $(0.0567)$ & $(0.0583)$ & & & $(0.0606)$ & $(0.0617)$ \\
\hline \multirow[t]{2}{*}{ Residence revealed } & & & -0.0295 & -0.0131 & & & 0.0890 & 0.0969 \\
\hline & & & $(0.2462)$ & $(0.2747)$ & & & $(0.2386)$ & $(0.2725)$ \\
\hline Residence revealed & & & -0.0803 & -0.0972 & & & -0.1566 & -0.1659 \\
\hline x Deprived suburb & & & $(0.2379)$ & $(0.2727)$ & & & $(0.2422)$ & $(0.2792)$ \\
\hline \multicolumn{9}{|l|}{ Controls: } \\
\hline Individual call & & $\mathrm{Y}$ & & Y & & $\mathrm{Y}$ & & Y \\
\hline Audit fixed effects & $\mathrm{Y}$ & Y & $\mathrm{Y}$ & Y & $\mathrm{Y}$ & $\mathrm{Y}$ & $\mathrm{Y}$ & $\mathrm{Y}$ \\
\hline$N$ & 154 & 154 & 154 & 154 & 142 & 142 & 142 & 142 \\
\hline$R^{2}$ & 0.0032 & 0.0081 & 0.0130 & 0.0178 & 0.0085 & 0.0115 & 0.0183 & 0.0222 \\
\hline$R^{2}$ with fixed effect & 0.8827 & 0.8833 & 0.8839 & 0.8844 & 0.8890 & 0.8893 & 0.8901 & 0.8905 \\
\hline
\end{tabular}

NotE: Estimates that are statistically significant at the 5\% level are in boldface. Standard errors in parentheses. Standard errors are clustered at the audit level. Each column reports the coefficients $\gamma$ and $\beta$ estimated along with a specific set of controls for each procedure. Name revealed (resp. residence revealed) is a dummy indicating whether the tester revealed his/her name in the phone conversation of the first procedure (resp. residential origin in the second procedure). Characteristics at the level of the individual phone calls are: a dummy indicating whether the tester used the phone line with a number starting with 09 (indicating Internet box) and a dummy indicating whether he/she called first. 


\section{Interviews}

This appendix provides a description of our interviews.

We interviewed 29 real-estate agents between June and October 2010. We divided the Paris region into six sub-regions (Paris / inner ring / outer ring, each subdivided in white-rich and minority-poor). Each of the six sub-regions was assigned to a research assistant, who had to interview five real-estate agents from the area (one research assistant only performed four interviews). We opted for this sampling strategy to maximize heterogeneity within the area covered by our audit study.

In each sub-region, we drew a list of agencies from Internet postings on http: / www. seloger.com, and research assistants were tasked with contacting agencies with a letter explaining the study (that we provided ourselves). There are two reasons why we avoided sampling the agencies we had audited. (1) We have been extremely cautious with avoiding suspicions of audit. Suspicious real-estate agents may purposefully distort their behavior, which would undermine the reliability of our findings. (2) It is impossible to infer discriminatory behavior from one particular pair of audits. Random reasons may explain why a rental unit was available to the white candidate and not to the minority candidate. Only consistent patterns of differential treatment reveal discrimination; these patterns only make sense within a quantitative framework. It would have been a logical stretch to treat these interviewees as discriminatory.

We did not compensate our informants and we guaranteed anonymity. Interviews consistently lasted about 60 minutes and took place at the agency. These were semi-structured interviews, for which we had provided the interview guide. The three main themes of the guide were: (1) context (informant's work history, description of her current job, of the neighborhood where she works); (2) a detailed account of how agents select tenants on behalf of landlords; (3) discrimination. To minimize social desirability concerns, we did not impose the discrimination theme; we let it develop organically from the discussion on selection practices. In such cases, an explicit question was also asked about "residence-based discrimination" in this section. We did not ask our respondents about their own discriminatory practices or their own attitudes toward minorities. All interviews were recorded and then transcribed; notes were taken during the interviews.

Summing the duration of the interviews, we obtained 1,665 minutes of audio recordings. The transcribed interviews single-spaced and written in 12 point font is 495 pages long. Additional information is available from the authors upon request. 


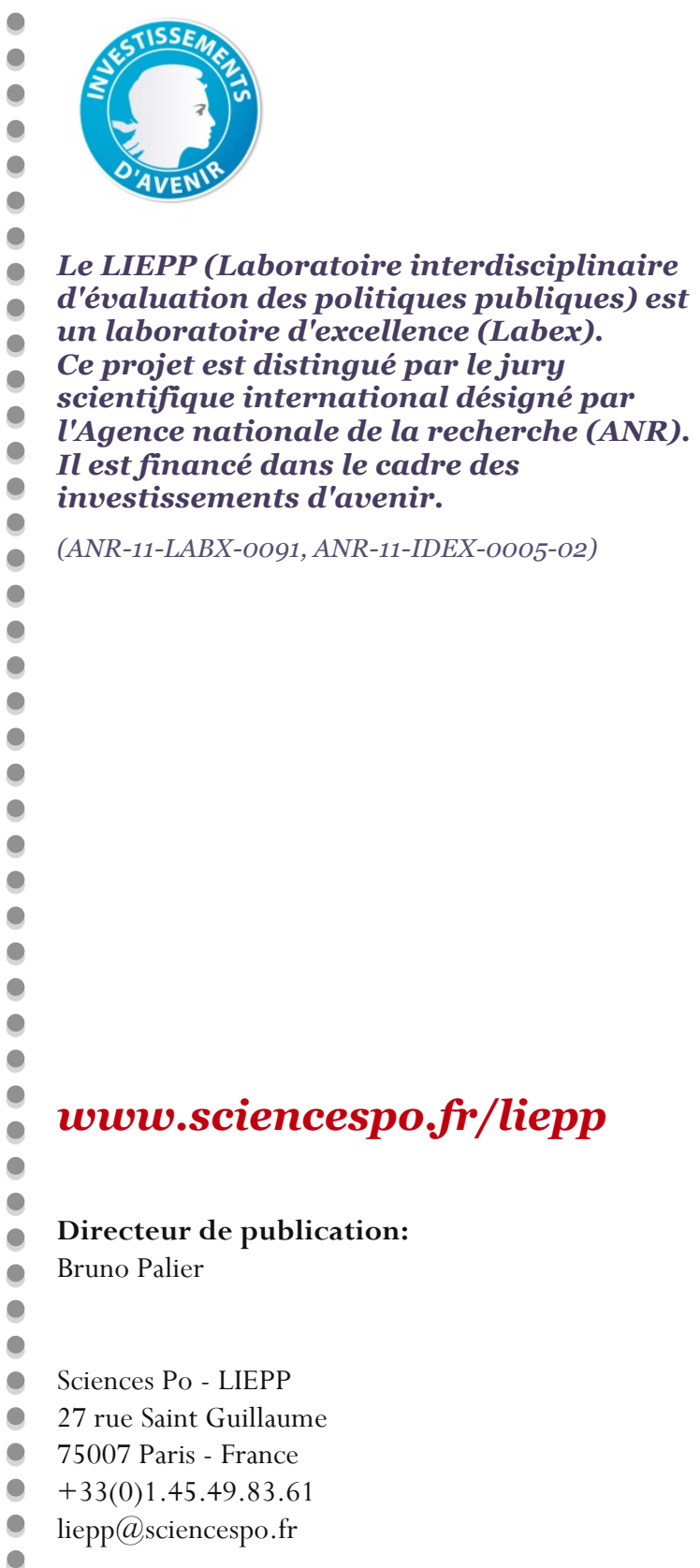

